\title{
Youth Life Satisfaction: A Review of the Literature
}

\author{
Carmel L. Proctor $\cdot$ P. Alex Linley $\cdot$ John Maltby
}

Published online: 26 August 2008

(c) Springer Science+Business Media B.V. 2008

\begin{abstract}
A central construct within the positive psychology literature is life satisfaction. Whereas adult life satisfaction has been studied extensively, the life satisfaction of children and adolescents has only received attention more recently. This article provides a review of the extant research on youth life satisfaction. Empirical studies $(n=141)$ on life satisfaction among youth are reviewed. The review details how life satisfaction among youth relates to various other important emotional, social, and behavioural constructs. Evidenced by the review are the conditions that foster positive life satisfaction and the implications of positive life satisfaction among youth. Future directions in life satisfaction research among youth are briefly discussed.
\end{abstract}

Keywords Life satisfaction - Adolescent - Children · Subjective well-being ·

Happiness · Review

Recently the burgeoning field of positive psychology has re-illuminated the need for psychology to address areas associated with optimal functioning and happiness. From the time of Aristotle (1925), the pursuit of happiness and the achievement of the 'good life' has been a major concern among philosophers and theologians, and was included as a foundational mission of psychology (Seligman 2002b; Seligman and Csikszentmihalyi 2000). Within the field of psychology the study of 'happiness' generally falls under investigations of subjective well-being (SWB) (see Diener 1984; Diener 1994; Diener et al. 1999, for reviews). The SWB construct is a tripartite category of phenomena, which includes: emotional responses (i.e. positive affect (e.g. joy, optimism) and negative affect (e.g. sadness, anger)), domain satisfactions (e.g. work satisfaction, relationship satisfaction), and global judgements of life satisfaction (LS) (Diener et al. 1999). In the research literature the components of SWB are often used interchangeably with each other and considered synonymous with term 'happiness' (Diener 1994; Seligman 2002a); despite that the term

C. L. Proctor $(\bowtie) \cdot$ P. A. Linley · J. Maltby

School of Psychology, University of Leicester, Lancaster Road, Leicester LE1 9HN, UK

e-mail: clp17@le.ac.uk 
'happiness' is not consistently defined and is associated with many varied meanings, including: hedonic level, joy, positive affect, satisfaction with life, and pleasantness. Considered to be the key indicator of SWB, LS is a subjective evaluation of overall quality of life (Diener and Diener 1995). Throughout the research literature, scores on measures of LS are often used to indicate happiness or unhappiness. In general, positive evaluations of LS are linked with happiness and the achievement of the 'good life', whereas negative evaluations of LS are associated with depression and unhappiness. Moreover, healthy psychological states, such as happiness and LS, are often assumed to be the by-products of social and economic resources and success, despite research indicating a bidirectional relationship (Lyubomirsky et al. 2005). Indeed, cross-sectional, longitudinal, and experimental data have all shown that well-being and happiness can precede diverse positive personal, behavioural, psychological, and social outcomes (see Lyubomirsky et al. 2005), just as low LS and unhappiness can predict the onset of depression and psychological disorder up to two years prior to diagnosis (see Lewinsohn et al. 1991).

\section{Understanding Youth Life Satisfaction}

Life satisfaction is an important construct in positive psychology (Gilman and Huebner 2003). Measures of LS are sensitive to the entire spectrum of functioning, and thus, provide indicators of both well-being and psychopathology. This contrasts with traditional mental health scales that require respondents to indicate the presence or absence of problems, and rate existing problems according to frequency and symptoms, with no option of reporting the characteristics or presence of positive feelings or behaviours (Gilman and Huebner 2003; Kamman et al. 1984). Further, as a key indicator of SWB, LS is integral to the science of positive psychology which focuses on identifying strengths and the building of them as buffers against the development of psychopathological problems (Veenhoven 1988).

\subsection{Purpose}

The purpose of this article is to provide a review of the extant research on youth LS, and detail how it relates to other important emotional, social, and behavioural constructs. Specifically, this article has been structured and organized such as to provide a source of reference for the research conducted in the area of youth LS. Further, although the majority of research studies conducted in this area have been correlational in nature, providing general positive and negative associations between LS and various variables, this article aims to specifically highlight the benefits of positive youth LS and draw attention to its role as a buffer against the negative effects of stress, psychological problems, and disorders. This review will not include a discussion or presentation of models and measures of LS or research on assessment of LS among youth (see Gilman and Huebner 2003; Huebner 2004, for reviews). Furthermore, throughout this review 'children' will refer to individuals aged 12 years old and under, 'adolescent' will refer to individuals aged 13-19 years old, and 'youth' will refer to groups of individuals comprised of both 'children' and 'adolescents'.

\subsection{Literature Search Strategies}

Literature included in this review was established using three search strategies. First, two major psychology databases: PsycINFO and PsycARTICLES, one medical database: 
PubMed, and one educational database: ERIC, were searched for peer-reviewed published literature in June 2006. Abstracts in each of these databases were searched using the following specific search terms: life satisfaction, youth, and adolescent. During each search the terms were paired (i.e. life satisfaction and youth, life satisfaction and adolescent). The search results from these specific search terms were then screened via the title and abstract for their relevance for inclusion in this review. Non-empirical (i.e. theoretical, literary review) publications, dissertations, and foreign language studies were not included, nor were studies for which the sample age group was greater than 19 years old. Using this strategy, a total of 392 abstracts were obtained for review. From the 392 abstracts reviewed, 122 empirical studies (i.e. English language) were identified. References obtained from the search performed using the first strategy are marked with an asterisk (*) in Appendix Table 1. It should be noted, however, that it was the initial aim of the first search strategy to collect all empirical studies of adolescent LS. In order to maximize the likelihood of retrieving all relevant studies the search term 'youth' was included. As a result, studies were gathered that included both samples of children and samples whose age ranges varied across the threshold between what is typically considered 'childhood' and 'adolescence'. Therefore, all studies whose sample age group was $<19$, that also met all the other inclusion criteria, were retained.

Second, using the ancestry method (see Anderson and Arsenault 1998) the 122 identified articles chosen for inclusion had their references screened by title for other relevant publications. These publications were then collected and this process repeated until no further references were derived. This process yielded an additional 15 empirical studies. References obtained from the search performed using the second strategy are marked with a double asterisk $(* *)$ in Table 1 of the Appendix.

Finally, references that were known by the author to be directly relevant to the review, but not detected using the other two search strategies, were also included. This process yielded a further 27 empirical studies. References obtained using the third strategy are marked with a triple asterisk $(* * *)$ in Table 1 of the Appendix. The three strategies employed yielded a total of 164 empirical studies, of which 23 relating to the psychometric properties of LS measures were not included. Therefore, a total of 141 empirical studies are to be reviewed. Included articles have been grouped under main areas of interest and are discussed in the sections that follow, where possible articles appear within the section matching the study focus groupings presented in Table 1 of the Appendix.

This review begins with a discussion of 'levels' of youth LS, the effects of demographics, and social desirability effects. Next, extant findings of youth LS satisfaction are summarized, and areas considered include: personality, physical health, productivity, relationships, environment, culture, risk-taking behaviour, disabilities, psychophysiology, psychopathology, extremely high LS, and character strengths. Finally, a brief discussion of youth LS as being more than an epiphenomenon is presented along with conditions fostering positive LS, the implications of positive LS among youth, and future directions.

\section{Levels of Life Satisfaction}

Cross-national data examining happiness among adults has shown that most people report a positive level of LS. For example, Diener and Diener (1996) reported that the mean level of happiness across 43 nations as measured on a scale that went from 0 to 10 , where $0=$ most unhappy, $5=$ neutral, and $10=$ most happy, was 6.33 . Based on surveys conducted at the University of Chicago, three in 10 people say they are 'very happy', one in 10 say they are 
'not too happy', and the remaining six out of 10 say they are 'pretty happy' (Myers and Diener 1996). Similar to findings of adult studies, most studies find that children and adolescents report their LS to be in the positive range. For example, Huebner et al. (2000a) found that $73 \%$ of 5,545 students sampled in grades 9-12 reported LS ratings in the 'mostly satisfied' to 'delighted' range. Similar findings of an overall positive level of LS among children and adolescents have been reported across various international studies (e.g. Greenspoon and Saklofske 1997; Huebner et al. 2000a, b; Kuntsche and Gmel 2004; Leung and Zhang 2000; Neto 2001; Nickerson and Nagle 2004; Park and Huebner 2005), as well as, among studies involving special groups (e.g. Brantley et al. 2002; McCullough and Huebner 2003). However, it is noteworthy that research findings also demonstrate that global LS tends to decline slightly with the onset and progression of adolescence and that these findings are similarly supported by international research, including those from: America (e.g. Suldo and Huebner 2004b), Israel (e.g. Ullman and Tatar 2001), South Korea (e.g. Park 2005), and China (e.g. Chang et al. 2003).

\section{Demographics and Life Satisfaction}

The relationship between demographic variables (i.e. age, gender, race, and socioeconomic status (SES)) and LS are weak and research has shown that these variables contribute only modestly to the prediction of youth LS. Further, these findings are consistently reported throughout the literature among the most frequently used global and domain specific selfreport measures of youth LS (see Gilman and Huebner 2000, for a review), including: the Students' Life Satisfaction Scale (SLSS: Huebner 1991b, c) (e.g. Adelman et al. 1989; Dew and Huebner 1994; Huebner 1991a, 1995; Huebner and Alderman 1993; Huebner and Dew 1996), the Multidimensional Students' Life Satisfaction Scale (MSLSS: Huebner 1994) (e.g. Adelman et al. 1989; Gilman and Huebner 1997; Gilman et al. 2000; Huebner 1994; Huebner et al. 1998), the Brief Multidimensional Students' Life Satisfaction Scale (BMSLSS: Seligson et al. 2003) (e.g. Funk et al. 2006; Huebner et al. 2000a, 2005; Seligson et al. 2005), and the Perceived Life Satisfaction Scale (PLSS: Adelman et al. 1989) (e.g. Huebner and Dew 1993a, b).

Several studies, however, have noted specific relationships between demographic variables and youth LS. For example, Huebner et al. (1998) found that age $(M=12.89)$ was weakly correlated with students' scores on the MSLSS domains. Ash and Huebner (2001) found that SES was positively related to LS (i.e. lower SES students reported lower LS than higher SES students); findings which are consistent with those reported by Neto (1993) using the Satisfaction With Life Scale (SWLS: Diener et al. 1985) with a Portuguese sample, and by Seligson et al. (2003) using the BMSLSS with a American sample, and further with those from adult samples (see Diener 1984). Similarly, Huebner et al. (2004b) reported a significant difference for race among American students using the BMSLSS, such that Caucasians reported higher LS than African-Americans.

\section{Social Desirability Effects}

The relationship between social desirability and self-report measures of SWB (e.g. LS) has traditionally been a matter of concern due to the moderate correlation between them (Diener 1994). However, social desirability has recently been demonstrated to be a personality characteristic that is an important determinant of well-being (Diener 1994; 
Huebner et al. 1998). For example, in two studies of Australian adolescents, Heaven (1989) found a significant correlation between the Lie subscale of the Eysenck and Eysenck (1975) Junior Eysenck Personality Questionnaire and LS, as measured by the SWLS, which indicated that respondents attempted to look favourable by 'faking good'. However, the correlations between LS and the other personality dimensions measured remained largely unaltered after partialing out the effects of social desirability (Heaven 1989). Comparatively, a study by Huebner et al. (1998) showed that the relationship between reports of LS and social desirability varied across the domains of the MSLSS, indicating the importance of social desirability as a determinant of LS (Gilman and Barry 2003; Huebner et al. 1998); results which contradict the notion that a correlation between the total scores of LS and a social desirability measures reflects bias in measures of SWB (see McCrae and Costa 1983).

\section{Personality and Life Satisfaction}

Personality and temperament variables have been demonstrated to account for most of the variance in SWB (Diener 1996; Emmons and Diener 1985; Fogle et al. 2002; Huebner 1991a). Therefore, the effects of personality and temperament variables on LS and the way in which these variables influence it are of great importance. As discussed by Diener (1996), the genetic and heritable effects of personality, including positive and negative affect and the influences of temperament, are evidenced from infancy and predispose individual levels of SWB (see Costa and McCrae 1980; DeNeve and Cooper 1998, for reviews of adult studies). Moreover, these heritable traits remain throughout life and thus have their greatest effect due to their stable long-term impact. Findings from adult studies which have examined the relationships among happiness, extraversion, neuroticism, and self-reported social competence, such as that by Argyle and Lu (1990a), suggest happiness is positively associated with extraversion and negatively associated with neuroticism, and that self-reported social competence acts as a mediator between temperament variables and happiness. Similar findings have been reported among children and adolescents (e.g. Ash and Huebner 2001; Casas et al. 2004; Greenspoon and Saklofske 2001; Heaven 1989; Huebner 1991a; McKnight et al. 2002). For example, Fogle et al. (2002) found LS to be positively correlated with extraversion and social self-efficacy, negatively correlated with neuroticism, and to mediate the relationship between LS and extraversion, but not between LS and neuroticism. Overall results suggested that adolescents' perceptions of their ability to be competent in social settings lead to increased sociability, which in turn related to greater LS. Similarly, Rigby and Huebner (2005) demonstrated that adaptive attributions for good outcomes served to partially mediate the relationship between emotional stability and LS; i.e. adolescents who were higher in emotional stability were more likely to make adaptive attributions for good outcomes, which in turn related to increased LS.

Life satisfaction has also been consistently positively associated with self-esteem. For example, Diener and Diener (1995) explored the discriminate validity of self-esteem and LS among a large cross-national group of 13,118 college students and discovered a positive correlation, not only across the entire sample, but also in most nations. Similarly, moderate positive correlations are found between LS and self-esteem among children and adolescents (e.g. Dew and Huebner 1994; Huebner 1991a; Neto 1993). In accordance with these findings, positive correlations have also been demonstrated between measures of LS and the Behaviour Assessment System for Children (BASC: Reynolds and Kamphaus 1992) Adaptive scales (i.e. self-esteem, self-reliance, interpersonal relations, and parental 
relations), and negative correlations between LS and the BASC Clinical Scales (i.e. anxiety, depression, and symptoms of psychological disorder). Moreover, these correlations have proved to be consistent across LS measures, including: the MSLSS (e.g. Gilman et al. 2000; Greenspoon and Saklofske 1997), the SLSS (e.g. Huebner et al. 2000b), and the BMSLSS (e.g. Funk et al. 2006).

\section{Physical Health and Life Satisfaction}

\subsection{Exercise}

Positive links have been shown to exist between youth LS and exercise. For example, Gilman (2001) found that students who either rated themselves higher in social interest, or as participating in greater numbers of structured extracurricular activities (SEAs), also reported significantly higher global LS than those who reported less social interest, and/or minimal or no participation in SEAs; similar findings have been found among adults (e.g. Argyle and Lu 1990b). Further, students who reported both low social interest and less participation in SEAs were lower across all satisfaction domains than those students who reported high social interest and greater participation in SEAs (see Gilman et al. 2004b; Larson 2000, for further findings and implications of SEAs for adolescents). In a related study, Vilhjalmsson and Thorlindsson (1992) demonstrated LS to be positively related to strenuous exercise, participation in club and group sport, and to be negatively correlated with anxiety, depression, psychophysiological symptoms, smoking, and alcohol use among Icelandic adolescents. Similar results have been reported among American students by Maton (1990), where LS was found to be positively related to meaningful instrumental activity, and by Valois et al. (2004b) where positive associations were found between LS and various physical exercise behaviours. Further, these results are consistent with those reported by Holstein et al. (1990) among a nationwide sample of Danish children, where it was found that high intensity exercise was positively associated with increased LS.

\subsection{Physical Health}

Evaluations of LS have become an important part of health outcome evaluations of medical treatment, such as health-related quality of life (HRQOL) evaluations targeted on patient groups suffering with mild physical disorders (Langeveld et al. 1999). For example, Langeveld et al. (1996) found that adolescents suffering with headache and migraine reported lower overall HRQOL, including: decreased psychological functioning, increased physical symptoms, lower LS, and less general health (Langeveld et al. 1996). Moreover, changes in headache and migraine activity in adolescents has been shown to be related to parallel changes in the HRQOL sub-domains of LS, health, and psychological functioning (see Langeveld et al. 1997). Further, additional studies have shown that increased headache suffering is associated with lower LS and that the experience of stress moderates the effects of headache on psychological functioning and LS in adolescents; i.e. increases in experienced stress is accompanied by poorer psychological functioning and lower global LS (Langeveld et al. 1999). Similar findings have been reported by Zullig et al. (2005a), where negative associations were found between LS and poor self-rated health, poor physical health, poor mental health, and activity limitation among adolescents; similar findings have been reported by Shek (1998c). Specifically, findings indicated that as the 
number of reported poor health days increased, the more LS decreased (Zullig et al. 2005a).

\subsection{Substance Abuse}

Substance abuse is typically considered the use of substances, such as alcohol or drugs, in ways that adversely affect life functioning (Forman et al. 2006). Out of all the substances used and abused by children and adolescents, alcohol, cigarettes, and marijuana remain the most widespread and prevalent (Forman et al. 2006). In a recent cross-cultural study of smoking behaviour among adolescents throughout Europe and America, it was found that $22.1 \%$ of American, $23.6 \%$ of Turkish, $57.6 \%$ of Polish, and $58.7 \%$ of Hungarian adolescents are self-reported smokers (see Piko et al. 2005). Overall, results revealed that LS, academic achievement, future orientedness, and social comparison orientation negatively correlate with smoking among adolescents across cultures (Piko et al. 2005). Similarly, Zullig et al. (2001) examined perceived global LS and selected substance use behaviours among American students and found that use of tobacco (i.e. cigarettes and chewing tobacco), cocaine, alcohol, marijuana, and steroids were all negatively related to selfreported LS (cf. Donohue et al. 2003). Related to these findings are those reported by Kuntsche and Gmel (2004), who examined binge drinking among Swiss adolescents and found that binge drinkers to had lower LS, more depression, and were more often offenders of bullying and hitting. More specifically, results revealed solitary binge drinkers to be the most socially inhibited, depressive, and victims of bullying in comparison to social binge drinkers, who were socially accepted but more often offenders of violence (Kuntsche and Gmel 2004). Similarly, Newcomb et al. (1986) examined whether alcohol use was a significant antecedent and/or consequence of low LS and found that early alcohol use led directly to an exacerbation of dissatisfaction with life and perceived environment as young adults.

\section{Productivity and Life Satisfaction}

\subsection{Employment}

Research with adult samples has indicated that loss of employment, and/or unemployment, impacts negatively on psychological well-being and can lower levels of self-esteem (Creed et al. 2003). Similarly, longitudinal research with adolescents has indicated that youths who leave school and do not subsequently become employed report lower levels of selfreported activity, perceived competence, and LS, and increased depressive affect (see Feather and O'Brien 1986). Further, longitudinal research has also revealed unemployed school-leavers to have increased depression, external LOC, and decreased self-esteem in comparison to employed school-leavers (see Patton and Noller 1984). In an Australian study, Creed et al. (2003) assessed students on levels of school achievement, well-being (psychological distress, self-esteem, LS), and career decision making self-efficacy (CDMSE). Nine months after leaving school, those employed full-time reported higher CDMSE and LS, more access to latent benefits, and less financial strain than full-time students, full-time students with part-time work, and those in the labour market but not currently employed. 


\subsection{Goals and Motivation}

According to Locke (2002), goal-directed action is the means by which we fulfil needs and attain happiness through the various processes of value application, value pursuit, and value achievement. For example, Linley et al. (2004, unpublished) found that children's intrinsic values were associated with increased happiness and LS, whereas extrinsic values were associated with lower teacher behaviour ratings; i.e. children with greater extrinsic values were perceived as displaying more negative behaviour than those with greater intrinsic values. These findings are in accordance with past research demonstrating that when one's life is organized around the pursuit of extrinsic goals, personal well-being is diminished, whereas the reverse is true of a life formed around the pursuit of intrinsic goals (cf. Casas et al. 2004; see Kasser 2004, for a review). Similarly, conscious goal pursuit (see Deci and Ryan 2000, for a discussion) has long been linked with increased SWB and happiness (Diener 1984). For example, past studies of college students have shown perceived goal attainment, goal importance, and goal fulfilment to be positively related to both positive affect and LS (see Emmons 1986; Emmons and Diener 1986). Similar results have been reported by Hofer and Chasiotis (2003) among Zambian adolescent males, where a congruence between implicit motives and self-attributed goals increased LS (cf. Hanrahan 2005). Interestingly results showed that level of education was negatively related to LS for all three motivational domains examined (i.e. achievement, affiliation, and power). These results suggest that contrary to other studies (e.g. see Diener et al. 1997), for Zambian adolescents, higher education and exposure to Westernized values may decrease LS as attainment of goals based on these values is difficult given socioeconomic conditions (Hofer and Chasiotis 2003). In a related study, Piko and Keresztes (2006) explored the relationship between physical exercise and life goals among Hungarian students and found that adolescents who are regularly active prefer less extrinsic values as life goals, whereas less active students prefer extrinsic aspirations as life goals. Further results revealed more active students to report better self-perceived heath, greater fitness, lower levels of depression, and higher levels of LS than less active students (Piko and Keresztes 2006). Comparatively, Lessing (1972) discovered that preadolescent girls with low LS projected their fantasies significantly farther into the future than their satisfied peers, whereas adolescents with low LS tended to constrict their future outlook in comparison to their more satisfied peers.

\subsection{Achieving Personal Standards}

Cognitive appraisal of personal standards is a characteristic common to both perfectionism, the setting of especially high standards, and LS (Gilman and Ashby 2003; see Gilman and Ashby 2006, for a review). Conceptually, perfectionism is seen as having two subtypes: adaptive and maladaptive (Gilman and Ashby 2003). From the maladaptive perspective, perfectionism is linked with negative mental health and psychological distress as achieving it often impossible and the striving after it leads many to be self-defeated and depressed (e.g. see Accordino et al. 1999; Enns and Cox 1999; Lombardi et al. 1998). Conversely, in line with Maslow's (1999) concept of self-actualization, perfectionism has adaptive positive mental health connotations as well. For example, Gilman and Ashby (2003) found significant positive relationships between the Standards subscale (i.e. personal standards) and significant negative relationships between the Discrepancy subscale (i.e. distress caused by the discrepancy between performance and standards) of a perfectionism measure 
and all of the MSLSS domains. Overall findings demonstrated that an inability to consistently meet personal standards was negatively related to domain LS, the ability to establish high standards was positively related to global LS, whereas difficulties in maintaining high standards was negatively related to global LS (Gilman and Ashby 2003). Similarly, Gilman et al. (2005), in their cross-cultural investigation of LS and perfectionism among American and Croatian children, found that both Croatian and American adaptive perfectionists groups reported higher satisfaction scores across the MSLSS domains than either maladaptive perfectionists groups or non-perfectionists groups.

\subsection{Hope}

Historically, scholarly work has defined hope as "the perception that one can reach desired goals" (Snyder et al. 2002, p. 257). According to modern hope theory, hope incorporates not only the capacity to conceptualize goals, but also the belief that one can find appropriate strategies to reach the desired goals (pathway thinking), and become motivated to use these discovered strategies (agency thinking) in order to achieve them (Lopez et al. 2004). Both pathway and agency thinking components involved in hope are necessary, but neither is sufficient, for successful goal attainment (Lopez et al. 2004; Snyder et al. 2002). Findings from the extant adult research on hope has showed that low hope is related to a number of negative psychological outcomes (Gilman et al. 2006). However, few studies have examined hope among children and adolescents aside from samples used during the initial validation of the Children's Hope Scale (CHS: see Snyder et al. 1997), and that of two studies which aimed to further validate the CHS with middle and high school students (see Valle et al. 2004). Expanding on previous hope work, Gilman et al. (2006) investigated various psychoeducational and psychological indicators of school adjustment and their relationships to adolescent students' levels of hope and found that both the Pathways and Agency subscales of the CHS were positively correlated to global LS, personal adjustment, grade point average (GPA), and SEAs, but negatively correlated to indicators of psychological distress, and school maladjustment.

\subsection{Self-Efficacy}

Self-efficacy, the personal belief in what one can do, or is capable of doing, is an important determinant of behaviour and influences whether and how one perseveres against the obstacles and challenges of life (Maddux 2002). In a study which investigated whether self-efficacy beliefs measured before the onset of major social change would moderate effects of social change on adolescent LS, future optimism, and educational success, Pinquart et al. (2004) assessed East German adolescents before and after the fall of the Berlin wall. Results indicated that those with higher levels of perceived negative social change and lower prior levels of self-efficacy had lower levels of LS and less future optimism after German unification, whereas higher LS and future optimism after German unification was associated with higher pre-unification self-efficacy beliefs (Pinquart et al. 2004). Overall, LS was found to be positively related to future optimism, GPA before unification, parental warmth, and self-efficacy, with pre-unification self-efficacy beliefs being found to buffer the effects of perceived negative consequences of German unification on LS and future optimism (Pinquart et al. 2004). Similarly, self-efficacy beliefs were found among the most consistent predictors of LS among adolescents from five sociocultural groups living in America (i.e. European, African, Chinese, Mexican, Dominican) 
(see Bradley and Corwyn 2004). In addition, results have demonstrated self-efficacy to be related to extremely high LS (e.g. Suldo and Huebner 2006) and for social self-efficacy to act as a mediator between extroversion and LS (e.g. Fogle et al. 2002).

\section{Relationships and Life Satisfaction}

\subsection{Parental Marital Status}

A salient factor pertinent to adolescent LS is parental marital status. Research findings on the psychological, emotional, and behavioural effects of divorce on children and adolescents have been mixed (Grossman and Rowat 1995), and research findings demonstrate that there is substantial variation in how children respond to the experience (Greene et al. 2006). On a general level, parental separation, divorce, and remarriage have been shown to be associated with diminished well-being in adolescents (Demo and Acock 1996), whereas more complex familial variables such as lack of paternal involvement have been shown to exert a greater negative effect (Flouri and Buchanan 2002; Grossman and Rowat 1995). For example, Grossman and Rowat (1995) found that perceived poor parental relationship, and not family status, was associated with reduced LS among a group of Canadian adolescents. These results are supportive of similar research, such as that conducted by Heaven et al. (1996) among Australian adolescents, where perceived family functioning was found to be positively associated with LS, self-esteem, and extraversion, and negatively associated with neuroticism and psychoticism. Related to these findings are results reported by Zullig et al. (2005b), where several aspects of family structure were found to be negatively related with LS, including: (1) living with other relatives, non-relatives, and guardians; (2) living with fathers only; and (3) living with mothers and another adult(s).

\subsection{Siblings}

Healthy adolescent adjustment is not only influenced by relationships with parents, but also by the quality of sibling relationships, especially during adolescence when complex socioemotional and cognitive changes are occurring (Oliva and Arranz 2005). For example, in a study of Spanish adolescents, Oliva and Arranz (2005) found that the sibling adjustment of boys was not related to any of the psychological or familial relationship variables measured (i.e. parental acceptance, parental supervision, intimacy, peer attachment, self-esteem, LS), but for girls positive correlations existed between all the variables measured. In contrast to the exploration of the influence of sibling relationships on adolescent LS, is the consideration of the differences that exist between only children and children with siblings. Many false beliefs have been noted in the literature about the disadvantages of being an only child, including: that only children are lonely, develop fewer social skills, are poorer at sports, are less happy, less popular with peers, overindulged by parents, forced into adult thinking too early, and overprotected, in comparison to peers with siblings (Veenhoven and Verkuyten 1989). Not discounting data highlighting the potential benefits of sibling relationships, various empirical studies have contradicted these beliefs. For example, data gathered from a sample of adolescents in the Netherlands has demonstrated that adolescent only children do not differ from peers with siblings on level of LS or pleasant affect, nor do they report lower levels of self-esteem or consider themselves less popular among peers, however they were found to participate less in, and feel less proficient at, sports (Veenhoven and Verkuyten 1989). 


\subsection{Social Support}

The perception of adequate social support from friends and family is an essential element of positive mental health, however research suggests that the need for support from parents and friends can shift across development. For example, among a sample of Canadian students, Burke and Weir $(1978,1979)$ found that adolescents were more likely to speak to peers about their problems, were more satisfied with the responses provided by their mothers and their peers than their fathers, and felt freer to take problems to their peers than to either their mothers or their fathers. Whereas, Greenberg et al. (1983) found that the effect of perceived quality of attachments to parents was higher than that of attachment to peers and accounted for a higher percentage of the variance in LS (Greenberg et al. 1983); results which contrast and compare with additional studies of American (e.g. Dew and Huebner 1994; Gilman and Huebner 1997; Larson and Richards 1991; Terry and Huebner 1995) and Chinese (e.g. Chang et al. 2003; Leung and Leung 1992; Leung and Zhang 2000; Man 1991) youth. These findings contrast those of studies that have found a greater reliance on peers in middle to late adolescence than in early adolescence. For example, Steinberg (1987) reported that adolescents' closeness to parents decreases and emotional autonomy increases with pubertal maturation (cf. Nickerson and Nagle 2004).

Adolescent LS has also been shown to be independently related to the extent of father, or father figure, involvement (Flouri and Buchanan 2002; Zimmerman et al. 1995). Past research has shown that fathers make a unique contribution to the happiness, LS, and psychological distress of their children (see Amato 1994, for a review). Further, various studies have shown that closeness to, involvement of, and nurturance from fathers is associated with psychological adjustment, reduced antisocial behaviour, intellectual development, social competence, and internal locus of control (LOC) among many other positive outcomes (see Amato 1994, for a review; Flouri and Buchanan 2002; Zimmerman et al. 1995). For example, Wenk et al. (1994) demonstrated that for both girls and boys feeling close to their father had a significant positive effect on LS. These results compare to those reported from a national survey of American youth where intrinsic support was found to be not only the most predictive facet of adolescent LS, but also that both perceived maternal and paternal support were equally important in predicting LS of adolescent males and females (cf. Vilhjalmsson 1994; see Young et al. 1995).

\subsection{Parenting Style}

Correlational research has highlighted the role of familial variables, such as, family structure, parenting style, parental emotional and social support, and family conflict, as crucial in the attainment of adolescent LS. For instance, Suldo and Huebner (2004b) found that all three dimensions of the authoritative parenting style: social support-involvement, strictness-supervision, and psychological autonomy granting were positively related to LS among adolescents, with perceived parental social support having the strongest correlation. Specifically, an interaction effect was found between LS and parental social support such that the influence of parenting behaviours on adolescent global LS decreased as age increased. In a related study, Ortman (1988) found that adolescents' feelings of social control and responsibility were positively related to LS among a group of students who reported having positive relationships with supportive parents. Studies of adolescents in China have revealed relationships between parenting style and adolescent LS similar found in the West. For example, Leung et al. (2004) found that perceived maternal concern was 
positively related to academic competence and that both were significant in predicting concurrent and longitudinal LS. More specifically, this study showed that overall satisfaction with family, school, and self significantly decreased as age increased, however satisfaction with friends did not significantly change over time (Leung et al. 2004); similar results have been reported by Park (2005) among South Korean students.

\subsection{Family Functioning}

Extensive literature exists on the negative influence of disruptive family events on adolescent well-being (McFarlane et al. 1995). For example, in a series of studies, Shek (1997a-c, 1998b, 2002a, b) has demonstrated negative correlations exist between LS and both parental and child indicators of parent-child conflict and poor family functioning among Chinese adolescents and their parents. Further, the data have generally indicated that increased parent-adolescent conflict and poor family functioning is related to increased mental health problems, problem behaviour, poorer academic performance, delinquent behaviour, and substance abuse (Shek 1997a-c, 2002a, b). Moreover, Shek (1999a-c, 2002c) has demonstrated that positively perceived parental qualities, parental styles, parental characteristics, and dyadic functioning predict positive adolescent LS; findings also suggested that paternal characteristics were more important than maternal characteristics in predicting LS in both males and females (cf. Shek 2005d).

Similarly, Shek (2003a, 2005b, e) has examined the relationship between perceived parenting behaviour, parental control processes, and parent-child relational qualities, family functioning and adolescent psychological well-being, substance abuse, and delinquent behaviour in a series of studies with Chinese adolescents with economic disadvantage. Results revealed that adolescents with economic disadvantage had relatively lower levels of LS and perceived parenting characteristics more negatively than noneconomically disadvantaged adolescents (Shek 2003a, 2005b). Additional studies revealed that current economic hardship and future economic worry are both related to lower levels of LS, emotional quality of life, self-esteem, and mastery, and increased levels of psychiatric morbidity, substance abuse, and problem behaviour (Shek 2003b, 2005c). Similarly, economically disadvantaged adolescents have generally been found to not only have lower LS and feel more hopeless, but also to perceive paternal behavioural control, and father-child relational qualities more negatively than adolescents whose families do not receive social assistance (Shek 2005e).

\section{The Environment and Life Satisfaction}

\subsection{Environmental Quality}

Low SES has long been linked with lower well-being among adults, however, the psychological and emotional effects of the quality of the physical environment provided to children from low SES families has been sparse (Homel and Burns 1989). Homel and Burns (1989) collected data from Australian children and their families from 18 different neighbourhoods and found that children from neighbourhoods with high problem levels, or who live on industrial or commercial streets, or reside in poorly maintained houses, and/or in rented accommodation reported lower overall LS, and less happiness with their families than children from residential neighbourhoods. These results are consistent with those reported by Nickerson and Nagle (2004) where parent and peer alienation was found to be 
inversely related to living environment satisfaction. Related to these findings are those reported by Wilson et al. (1997) from a longitudinal study of rural adolescents from America's Appalachian region. Results revealed a variety of variables, including: (1) family's SES, community size, marital status; (2) perceived attainment in job and life goals, and self-esteem; and (3) perceived disparity between job aspirations and job opportunities, educational demands and educational aspirations, desired residence and actual residence, and desired children and actual number of children, to be predictors of LS among economically dispossessed Appalachian youth (Wilson et al. 1997); similar results have been found among young Appalachian adults (see Wilson and Peterson 1988).

\subsection{Relocation}

Family residential relocation is ever increasing as individuals seek better employment and opportunities in different geographical regions. The effects on the psychological wellbeing of children and adolescents as a result of relocation is evidenced through LS having been demonstrated to be negatively associated to the number of moves made and positively associated to a child's length of time in residence (see Brown and Orthner 1990). For many children and adolescents, however, relocation does not necessarily involve moving with their family, but moving into a residential care situation due to environmental difficulties occurring with their own family. Unfortunately though, residential treatment settings are generally viewed negatively and it is often assumed that things get worse for children following such placement. For example, Sastre and Ferriere (2000) examined the LS reports of French adolescents living in residential treatment centres and found that these adolescents had lower LS than matched adolescents living at home with their families. In contrast, Gilman and Handwerk (2001) found among American adolescents that shortly after arrival, self-reports of LS were positive and that after several months improved across a number of domains. Similarly, Gilman and Barry (2003) found decreases in global LS after the first month of arrival into residential treatment, but this was followed by significant increases across the next two months. These findings suggest that adolescents may experience added stress upon first entering a residential treatment facility, but following this their LS increases due to the nature of the treatment and environment provided (Gilman and Barry 2003; cf. Schiff et al. 2006).

\subsection{Life Events}

Proponents of the view that personality controls most of the variance in SWB, such as Costa and McCrae (1980), suggest that SWB is highly stable over time even though research with adults has shown only moderate stability in SWB scores (Headey and Wearing 1989). Recently, research has been put forth demonstrating that changes in SWB are the result of major life events and experiences. For example, Headey and Wearing (1989) found that life events during a two year period significantly effected SWB over and above the effects of personality. In addition to studies of major life events, there is growing interest in the role of minor life events (e.g. daily hassles, everyday stressors) in changes in SWB, and LS particularly. For example, McCullough et al. (2000) found that minor daily events (e.g. fights with friends, doing poorly on an exam, enjoying a hobby, helping other people) contributed unique variance over and above that of major life events (e.g. death of family member, divorce) (see Braithwaite and Devine 1993; West and Prinz 1987, for the effects of parental alcoholism); similar results have been found by Ash and Huebner 
(2001). In a related study, Suldo and Huebner (2004a) found negative correlations between LS and stressful life events, externalizing behaviour, and internalizing behaviour (see Funk et al. 2006; Huebner and Alderman 1993; McKnight et al. 2002, for similar findings). Further, results demonstrated that LS scores remained stable and were significant predictors of externalizing behaviour one year later; similar results have been reported by Huebner et al. (2000b). Overall, analyses revealed an interaction effect between LS and stressful life events, such that externalizing behaviour was predicted by stressful life events only for those with low LS. This interaction provides support that LS acts as a buffer against psychopathological behaviour.

\section{Culture and Life Satisfaction}

\subsection{Acculturation}

Several notable studies have focused on the acculturation and psychological adaptation of adolescents of non-European decent living in Western societies for whom LS may differ across social, situational, and personality factors. For example, Bradley and Corwyn (2004) found that the most consistent predictors of LS were those pertaining to self-efficacy, taskorientation, health, and marital status of parents among five sociocultural groups (European, African, Chinese, Mexican, and Dominican) living in America. In contrast, Leung et al. (2006) found that differences in levels of LS among three immigrant Asian groups (Chinese, Filipino, Vietnamese), and their successful adaptation in Australia, could be explained by migration circumstances (i.e. voluntary or refugee), cultural differences (e.g. emphasis on education), and the ability of the cultural group to support the adolescent (e.g. presence of pre-existing English speaking immigrant community). In Finland, Liebkind and Jasinskaja-Lahti (2000) found that perceived discrimination increased acculturative stress and behavioural symptoms and reduced LS, whereas perceived parental support, acceptance of parental authority, and length of residence increased LS among immigrant adolescents from the former Soviet Union, Turkey, Somalia, and Vietnam. Similar results can be found among additional studies conducted in America (e.g. Phinney and Ong 2002), Portugal and France (e.g. Neto 1995, 2001), Norway and Sweden (e.g. Sam 1994, 1998, 2000; Virta et al. 2004), Israel (e.g. Hofman et al. 1982; Ullman and Tatar 2001), the Netherlands (e.g. Verkuyten 1986, 1989), and with adults (e.g. Van Selm et al. 1997).

\subsection{Cross-Cultural Comparisons}

Imperative to the study of children's well-being are cross-cultural comparisons that allow exploration of the generalizeability of findings from Western cultures to children and youth from other cultures (Park and Huebner 2005). For example, Liu et al. (2005) found that Chinese students scored higher on the dimensions of Friends, School, and general LS than American students. Similarly, Park and Huebner (2005) compared the LS reports of Korean and American students and found that Korean students reported lower LS than their American counterparts; results which are consistent with those reported in adults studies (e.g. Diener and Diener 1995). The greatest differences were found in the Self and School domains, with Korean students reporting significantly less satisfaction in the Self domain and American's reporting less satisfaction in the School domain (cf. Park et al. 2004a). In a related study, Tanaka et al. (2005) found that Japanese students report higher numbers of 
physical and psychiatric symptoms, less happiness, and more stressful life events, and considerably lower levels of LS than Swedish adolescents. These results highlight that specific and important differences in both global and domain specific LS exist among adolescents from different cultures. Furthermore, these findings are consistent with, and can be interpreted in terms of, theories regarding value differences that exist between individualistic and collectivistic cultures (see Oishi et al. 1999a, b).

\subsection{Cultural Values}

The values, beliefs, and behaviours of one's cultural group, and the perception and treatment of that cultural group by society at large, can affect the psychological well-being of ethnic minority adolescents. For example, Constantine et al. (2006) examined the relationships between Africentric cultural values, self-esteem, perceived social support satisfaction, and LS among a group of African-American adolescent girls and found LS to be positively related to adherence to Africentric values, and self-esteem, but not to perceived social support satisfaction (cf. Brown et al. 2001). Related to these findings, longitudinal examination of the relationship between Chinese cultural belief about adversity and psychological well-being and problem behaviour has revealed that those with lower levels of endorsement of Chinese cultural beliefs about adversity have lower LS, and higher levels of problem behaviours and substance abuse, than those with positive endorsement (see Shek 2004, 2005a).

\section{Risk-Taking Behaviour and Life Satisfaction}

\subsection{Violence}

There is a paucity of research that has examined the relationship between adolescent LS and health-risk behaviours, especially those which may lead to premature morbidity and mortality such as violence and aggression (Valois et al. 2006). The results of a study by Valois et al. (2001) have demonstrated that LS is negatively associated with many adolescent risk behaviours, including: physical fighting, fighting requiring medical treatment, carrying a gun, carrying a weapon, and carrying a weapon at school; similar results have been reported by Valois et al. (2006). Negative relationships have also been demonstrated between LS and feeling un-safe while at school, travelling to and from school, being threatened or injured by someone with a weapon, having property stolen or damaged, and riding in a car with an impaired/drinking driver (see Valois et al. 2001). Similarly, MacDonald et al. (2005) reported that students with increased LS were less likely to have carried a weapon in general, or on school property during the past 30 days, or carried a gun or reported engaging in physical fights during the preceding 12 months. Moreover, students in the bottom quartile of LS, but in the top quartile of cigarette smoking and sexual promiscuity, were found to report higher involvement in violent behaviour compared to those reporting higher LS and not participating in such risk-taking behaviours.

\subsection{Victimization}

Many young people report that they have been the victims of either physical or emotional violence during a dating relationship (Callahan et al. 2003). Physical and 
emotional abuse that occurs in an adolescent relationship can have a more harmful effect on psychological well-being than it does during adulthood, due to adolescents' lack of experience and resources in this area. For example, Callahan et al. (2003) found a negative relationship between dating violence and LS for both boys and girls. Further, increases in dating violence were found to contribute to increased posttraumatic stress, anxiety, depression, and dissociation. Similarly, Coker et al. (2000) addressed the impact of severe dating violence (SDV) and forced-sex victimization and perpetration on adolescent LS. Of 5,414 adolescents sampled, 12\% self-reported SDV as a victim or perpetrator in the past 12 months. Overall, results demonstrated that SDV and forcedsex are associated with poor mental and physical health, low LS, and adverse health behaviours such as suicide ideation/attempts in adolescent female victims and male perpetrators (Coker et al. 2000). Related to these findings is the negative effect of peer victimization through bullying on adolescent LS. The detrimental effect of bullying on mental health has been suggested in various studies in many countries (e.g. Norway, Ireland, Australia, England and Canada) (see Rigby 2000). For example, Flouri and Buchanan (2002) found among adolescent males living in Great Britain that psychological well-being was independently related to the degree of bullying experienced at school.

\subsection{Sexual Behaviour/Pregnancy}

There is a paucity of research that has examined the potential detrimental effects of youth engaging in sexual risk-taking behaviour, such as, victimization, substance abuse, and adolescent pregnancy. Acknowledging this, Valois et al. (2002) examined the sexual risktaking behaviours among 4,758 American adolescents and found negative relationships between LS and various sexual risk-taking behaviours, including: ever having had sexual intercourse, age of first intercourse, having had two or more lifetime intercourse partners, having had one or more intercourse partners (past 90 days), using alcohol/drugs at the last act of sexual intercourse, not using a condom at last intercourse, not using contraception at last intercourse, having been forced to have sex, forcing someone to have sex, having been beaten up by a date, and having beaten up a date (in last 12 months). Related to these findings are the numerous and interacting factors which contribute to adolescent pregnancy and parenting which may result from a youth's decision to engage in sexual risk-taking behaviour (Stoiber and McIntyre 2006). The adolescent pregnancy and parenting literature suggests two broad categories of contributing factors: dispositional and situational characteristics (see Stoiber and McIntyre 2006). In general, adolescent pregnancy rates are disproportionately higher for those teens most effected by situational factors, such as low SES. Recent research, however, has highlighted the salience of family dynamics, structure, and dysfunction in understanding adolescent pregnancy among ethnic minorities, and has shown that families with poor communication and relationship styles, increased parent-child conflict, low goal orientation, and physical or sexual abuse have more teens who become pregnant (Jaffee et al. 2001). Assertions which have been supported by research conducted by Guijarro et al. (1999) among pregnant and non-pregnant teens from Ecuador and among additional studies conducted in America (e.g. Schilmoeller et al. 1991; Stevenson et al. 1999; Unger and Wandersman 1988). 


\section{Disabilities and Life Satisfaction}

\subsection{Physical Disabilities}

In general results from the adult literature suggest that disabled adults report positive levels of LS, even among those with multiple handicaps and social complications (see Diener and Diener 1996). Evaluations of LS among children and adolescents with disabilities are sparse, especially those taking into consideration the specific effects of school and environmental variables. In a study of LS among Deaf/Hard-of-Hearing (D/HH) youths, Gilman et al. (2004a) found that both segregated residential and day school D/HH students reported both lower global and domain specific LS than non-D/HH students. Further, residential $\mathrm{D} / \mathrm{HH}$ youth reported significantly lower LS than $\mathrm{D} / \mathrm{HH}$ day school youth (though for the residential $\mathrm{D} / \mathrm{HH}$ group $50 \%$ of the total variance was accounted for between the School and Living Environment variables).

\subsection{Mental Disabilities}

Important to the study of LS is determination of what differences exist in the way average and mentally disabled students formulate their judgements of quality of life and if measurement instruments validated in the general population generalize to special groups of individuals. For example, using the MSLSS Brantley et al. (2002) compared the LS reports of students with mild mental disability (MMD) with a matched sample of typically achieving (TA) students and found that MMD students reported lower satisfaction in the Friends domain than did TA students, whereas the opposite was true in the School domain. In addition, MMD students in a self-contained education setting had significantly higher School satisfaction than MMD students in a regular educational setting (Brantley et al. 2002). Further, Huebner et al. (2002) determined that the correspondence between parent and adolescent reports for the non-MMD students were very high and consistent with results found in adult studies (cf. Diener 1994), but ranged from low to non-significant for the MMD students (cf. McCullough and Huebner 2003). Similarly, increasing awareness of the effect of community integration and inclusion for children and adolescents with intellectual disabilities has been growing. Results of an Australian study of community belongingness and LS among intellectually disabled students, for example, has indicated that LS is significantly correlated with levels of activity, friends, and support within the community (see Bramston et al. 2002). Further, studies have shown that adolescents with intellectual disability report lower use of community facilities, and feel less belongingness and control over their choices than their matched peers (Bramston et al. 2002; cf. Pretty et al. 2002).

\section{Psychophysiological Problems and Life Satisfaction}

\subsection{Eating Disorders}

The Diagnostic and Statistical Manual of Mental Disorders, Fourth Edition (American Psychiatric Association 1994) of the American Psychiatric Association lists two specific eating disorder diagnoses: anorexia nervosa (AN) and bulimia nervosa (BN). More than $90 \%$ of $\mathrm{AN}$ and BN cases occur in females during late adolescence (mean age of onset of 17) (American Psychiatric Association 1994). Studies have shown eating disorders to be 
related to numerous negative psychological, personality, and behavioural factors, such as, neuroticism, perfectionism, negative self-evaluation, depression, and low self-esteem (Halvorsen and Heyerdahl 2006; Lombardi et al. 1998). Similarly, research has shown adolescent LS to be negatively associated to neuroticism (e.g. Huebner 1991a), low selfesteem and depression (e.g. Gilman et al. 2000), poor self-concept (e.g. Dew and Huebner 1994), and maladaptive perfectionism (e.g. Gilman et al. 2005). Concordant with these findings is the association between LS and AN. For example, a long-term follow up of childhood- and adolescent-onset females sufferers of AN in Norway showed significantly lower LS when compared to a sample of normal females (see Halvorsen and Heyerdahl 2006). Although found to have similar levels of self-esteem at follow up, former AN patients with no present eating disorder who had achieved normal eating attitudes had lower LS when compared to women in a large population study (Halvorsen and Heyerdahl 2006).

\subsection{Obesity}

Dietary habits formed during childhood and adolescence effect those practiced throughout adulthood. Increases in obesity are occurring worldwide and many health experts are considering this growing trend an epidemic. Being overweight or obese during childhood increases the risk of a myriad of health related diseases, and psychological (e.g. depression, negative self image, low self-esteem) and psychosocial (e.g. bullying, fewer friendships, physical and verbal abuse) problems, that may persist into adulthood (Blom-Hoffman et al. 2006). For example, results of a study conducted among Kuwaiti schoolchildren (see Honkala et al. 2006) have demonstrated assessed LS variables (i.e. overall happiness, loneliness, number of close friends) to be associated with more-than-once-a-day consumption of sugar products. Further, significantly more children consuming sugar products more-than-once-a-day where among those who did not feel happy and/or often felt lonely (Honkala et al. 2006). Similarly, Valois et al. (2003) found LS to be negatively related to poor perceptions of body weight, trying to lose weight, dieting to lose weight, vomiting or using laxatives to lose weight, and taking diet pills to lose weight among American adolescents. In contrast, results of a Danish study found a healthy diet to be significantly associated with positive adolescent LS (see Due et al. 1991).

\section{Psychopathology and Life Satisfaction}

As noted by Greenspoon and Saklofske (2001), until the last few decades the absence of psychopathology (PTH) has been considered indicative of positive mental health and SWB. However, great strides in changing this view have occurred along side the paradigm shifts in psychology that have been brought about by the positive psychology movement. This movement has elucidated the need for psychologists to assess SWB and PTH together through an integrated system. Of particular concern are those individuals who do not fall within the usual (high-SWB/low-PTH and low-SWB/high-PTH) unidimensional model of mental health; i.e. those exhibiting low-SWB/low-PTH and high-SWB/high-PTH. Support for an integrated system has been provided by Greenspoon and Saklofske (2001) who administered a battery of measures assessing SWB (i.e. the five dimensions of LS measured by the MSLSS) and PTH (i.e. interpersonal relations, behaviour, temperament, personality, self-perception) to a sample of Canadian children classified as either high or low in SWB and PTH. Results confirmed a 100-300\% increase above chance classification 
for low SWB/low PTH and high SWB/high PTH groups, suggesting the potential utility of a dual-factor system; however, further studies are required with adolescent populations in order to assess the applicability of the model across a broader age sample.

\subsection{Depression}

In general, research findings from adult studies have confirmed that depression and LS are strongly negatively correlated to the point that they are near opposites (Headey et al. 1993). Such findings have also been substantiated through research with children and adolescents where self-reports of LS and depression have been compared (e.g. Funk et al. 2006; Gilman and Huebner 2006; Greenspoon and Saklofske 1997). For example, Adelman et al. (1989) found that American students referred for mental health services had lower LS, less perceived control at school, and higher levels of depression in comparison to those attending in regular classrooms; similar results have been reported by Smith et al. (1987).

\subsection{Loneliness}

Despite that loneliness is a universally experienced human emotion, until recently there has been a dearth of psychological research devoted to this area (Asher and Hopmeyer 1997). Several possible explanations for why children experience loneliness have been put forward, including: deficiencies in the parent-child relationship, inability to form close intimate friendships, poor peer acceptance, peer victimization, and negative subjective evaluations of parent and/or peer relationships (Asher and Hopmeyer 1997). Among adolescents, investigations into the correlates of loneliness suggest that personal characteristics are associated with increases in the experience of loneliness. Moore and Schultz (1983), for example, found loneliness to be positively correlated with state anxiety, LOC, depression, public self-consciousness, and social anxiety, and negatively correlated with self-reported attractiveness, likeability, happiness, and LS among American adolescents. Similar results have been reported by Neto (1993) in a sample of Portuguese adolescents where it was found that loneliness, social anxiety, and shyness were all negatively correlated with LS. Related to these findings are those reported by Morojele and Brook (2004) from a sample of South African students, where it was found that meaninglessness was positively correlated with depression and negatively correlated with knowledge of HIV status and LS.

\subsection{Suicide}

Adult studies have suggested a link between low LS and suicide behaviour, with similar results being found among adolescents (Valois et al. 2004a). For example, a study by Valois et al. (2004a) revealed negative associations between LS and poor mental health, poor mental/physical health days, serious suicide consideration, planning for suicide, attempted suicide, and suicide attempt requiring medical care among adolescents. In a related study, Thatcher et al. (2002) reported that several independent variables were significantly associated with attempted suicide either directly or indirectly though antecedent and moderating variables. For example, for Caucasian males global LS moderated the relationship between the antecedent variables of threatened or harmed at school and duration of alcohol use and attempted suicide. Additional antecedent variables associated 
with global LS included: physical fighting, property stolen at school, using pills to loose weight, beating up the person you are dating, age of first alcohol use, use of marijuana at school, and exercise (Thatcher et al. 2002).

\subsection{Emotional Disturbance}

Although measures of positive SWB have been demonstrated to complement information derived from psychopathological evaluations (Cowen 1991), there is a paucity of research which has investigated their usefulness with children who have been classified with serious emotional and behavioural disorders (Griffin and Huebner 2000). In a study aimed at providing initial support for the potential utility of LS measures with students identified as seriously emotionally disturbed (SED), Griffin and Huebner (2000) administered the MSLSS to students classified as SED and non-SED students. Results revealed no significant effect of group membership between SED and non-SED students on their global LS reports. In a similar study, the ability of the SLSS to discriminate between clinically diagnosed students classified as Emotionally Handicapped (EH) and non-EH students was examined by Huebner and Alderman (1993). A group of non-EH students and a group of students classified as Educably Mentally Handicapped (EMH) were combined and compared to the EH group. Results revealed the EH students to have significantly lower LS than both the combined non-EH/EMH group and a group of learning disabled students (Huebner and Alderman 1993). In addition to these findings, studies have demonstrated that youths suffering with emotional (i.e. poor perceived mental health, dissatisfaction with life, and unhappiness) and behavioural (i.e. interpersonal problems at home and school) problems are less likely to report poor mental health and behavioural problems in comparison to parental or caregiver reports of their mental health (e.g. see Roberts et al. 2005).

\subsection{Insomnia}

Adolescents and children who suffer from sleep disorders or lack of sleep due to insomnia have been found to report more psychopathological, psychophysiological, and psychosomatic problems, including: depression, anxiety, headache, stomach-ache, and fatigue, than adolescents with no sleep disturbances (Roberts et al. 2002). For example, a study by Roberts et al. (2002) examined the impact of insomnia on somatic, interpersonal, and psychological functioning among American youths and found that baseline insomnia increased the subsequent risk of psychological (i.e. self-esteem, LS, perceived mental health, and depression) dysfunction one year later. Moreover, results demonstrated that those with moderate levels of insomnia at baseline had an elevated risk of dysfunction one year later and this risk increased with increased levels of insomnia.

\section{Extremely High Life Satisfaction}

Recent studies have suggested that there are numerous personal benefits associated with very high levels of LS. For example, Suldo and Huebner (2006) examined whether extremely high LS was associated with adaptive functioning or maladaptive functioning among American high school students, and found that students who reported very high levels of LS benefited from many positive outcomes, including: the highest level of social support from all sources, the least number of internalizing and externalizing behaviour 
problems, the lowest levels of neuroticism, significantly higher levels of academic, emotional, and social self-efficacy, the lowest emotional and behavioural problems, and superior interpersonal and cognitive functioning, than those with average and low LS. In a similar study, Gilman and Huebner (2006) found high levels of adolescent LS to be positively related to GPA, SEAs, interpersonal relations, parental relations, self-esteem, and hope, and to be negatively related to poor attitude towards school, poor attitude towards teachers, social stress, anxiety, depression, and external LOC. Further, adolescents reporting high LS had higher scores on all measures than those reporting low LS, and reported significantly higher scores on measures of hope, self-esteem, and (internal) LOC, but lower scores on measures of social stress, anxiety, depression, and (negative) attitudes towards teachers, than those reporting average LS (Gilman and Huebner 2006). Moreover, none of the adolescents in the high LS group demonstrated clinical levels of psychological symptoms compared to $42 \%$ of the low LS group and $7 \%$ of the average LS group. These findings contrast with those found among gifted students for whom it has been suggested that superior intellectual ability leads to increased well-being, however findings have failed to support this hypothesis (see Ash and Huebner 1998).

\section{Character Strengths and Life Satisfaction}

Examinations into the relationships between character strengths (i.e. virtues) and life satisfaction are still just beginning, however, findings from initial studies in this area have illuminated particular strengths of character to be associated with increased LS among both adults and children (see Peterson and Seligman 2004b, for a classification of character strengths). For example, in a study designed to further the development and validation of the Values In Action-Inventory of Strengths for Youth (Peterson and Seligman 2004a), Park and Peterson (2006b) found that similar to the findings of adult studies (see Park et al. 2004b) the strengths of hope, love, gratitude, and zest were found to be linked to greater LS among children. Further, examination of the parental strengths of character that predicted the LS of their children revealed that the same strengths of character associated with greater LS among children (i.e. hope, love, gratitude, zest) were the strongest parental predictors. Additionally, results revealed parental self-regulation to be associated with child LS (Park and Peterson 2006b). Similar findings have been reported by Park and Peterson (2006a) among young children through examination of free parental descriptions of children's personal characteristics and individual qualities. Results revealed three strengths of character to be related to happiness: love, hope, and zest. These findings diverge from previous studies in that the strength of gratitude, which is a strong predictor of LS among youth and adults, was not included. However, examination of descriptions of children aged seven and over revealed the expected correlation between LS and gratitude (Park and Peterson 2006a).

\section{Discussion}

\subsection{Life Satisfaction: More than an Epiphenomenon}

The field of positive psychology has reawakened empirical investigations into understanding how we achieve happiness and the 'good life'. This shift away from an almost exclusive emphasis on psychopathology to an increased emphasis on the positive end of 
the mental health spectrum has enabled researchers to investigate what makes life worth living (Fabricatore and Handal 2000). Fundamental to the underlying mission of discovering how we achieve happiness is determining the way in which youth perceive their lives. The youth LS literature provides clear evidence to suggest that youth LS is more than just an outcome of various psychological states (e.g. positive affect, self-esteem), it is also an influential predictor of psychological states and psychosocial systems (e.g. depression, physical health) (Gilman et al. 2004a). Support for conceptualizations of LS as more than just an epiphenomenon can be found among recent research that has highlighted its role as a mediator and moderator between the environment and behaviour. For example, Suldo and Huebner (2004b) demonstrated that LS mediates the relationship between the social support-involvement dimension of authoritative parenting and adolescent problem behaviour. Further, support has been provided for the potential mediating role of LS between stressful life events and internalizing behaviour (see McKnight et al. 2002). In addition, there is recent evidence to suggest that increased LS buffers against the negative effects of stress and the development of psychological disorder. For example, adolescents with positive LS have been demonstrated to be less likely to develop later externalizing behaviours as a result of stressful life events than adolescents with low LS, suggesting that LS acts as a moderator for (i.e. buffer against) externalizing behaviour (Suldo and Huebner 2004a).

\subsection{Conditions Fostering Positive Life Satisfaction}

Notwithstanding the genetic and heritable effects of personality, such as, positive and negative affect and temperament, there are many environmental, familial, and social conditions which foster positive youth LS. Among these are the fundamentally positive outcomes on LS that emerge as a result of a healthy lifestyle, good physical health, exercise, and participation in sports and social activities. Conversely, non-participation in risk-taking behaviour, including: substance abuse (e.g. alcohol, tobacco, and illicit drugs), violence, aggression, and sexual victimization, is associated with elevated levels of LS. Similarly, environmental quality, such as, living in a safe neighbourhood, residing in a well maintained home, infrequent relocation, good familial and parental relationships, and social support, all engender positive youth LS.

Expanding on past correlational research which has highlighted the many positive conditions that foster positive youth LS, is the exploration of the causal pathways, including cognitive mediators and moderators, that may aid in understanding how personality and the environment influence youth LS (Huebner et al. 2004a). For example, Ash and Huebner (2001) demonstrated that adolescent LS was mediated by LOC orientation (i.e. frequent negative life events were related to decreased perceptions of control, which was related to lower LS). Similarly, Fogle et al. (2002) demonstrated that social selfefficacy mediates the relationship between extraversion and LS. That is, positive perceptions of social capabilities (i.e. social self-efficacy) served as the mechanism through which extraversion effected LS (Fogle et al. 2002).

\subsection{Implications of Positive Life Satisfaction}

Recent research has indicated the potential role of LS as a buffer against negative effects of stress and the development of psychopathological behaviour (e.g. Suldo and Huebner 2004a). Such findings are highly significant to the promotion of positive development in 
youth. In general the research literature suggests that most youth report a positive level of LS. However, concern must be focused on those who fall below this average and how what we know about the relationships between LS, psychopathology, personality, and the environment can aid in the development of strategies aimed at increasing LS among these youths. For example, a survey of 5,544 American students found that $11 \%$ of those sampled fell below the neutral point with $7 \%$ indicating a 'terrible' or 'unhappy existence' (see Huebner et al. 2000a). The importance of increasing low LS to normative levels and further maintaining those positive levels of LS among youth cannot be overemphasized. Further, attention needs to be drawn to the fact that those benefiting from rich environmental and social resources do not necessarily display high levels of LS, which may aid in protecting them against the negative effects of stress and the development of psychopathological behaviour. In line with the positive psychology movement, learning how to build strength in order to buffer against the development of problems is imperative to the positive development of young people. Youth LS is one such strength. Incorporation of LS reports in the assessment, evaluation, and implementation of educational and social programmes is essential in order to provide insight into the differential effects and impacts of such services on the quality of life of youths receiving them and help identify where crucial changes should occur in order to for increases in LS to ensue.

\subsection{Future Directions}

Clearly LS is a key component in the attainment of positive mental health and is a determinant of many life outcomes. Although research into the correlates and consequences of youth LS is not as extensive as that available for adult populations, research findings to date have illuminated potential applications and implications of the findings from the extant research across broad educational, psychological, and social arenas. Additional research is required in order to further discover causal pathways through which personal and environmental factors effect and influence how youths' perceive their lives. However, the implications of the various ways in which understanding levels of youth LS can aid in the evaluation, implementation, and assessment of programmes designed to build strength as opposed to repairing damage, cannot be underscored.

In general, this review has presented the extant findings in the youth LS literature. Specifically, the literature demonstrates the need for research among children and adolescents across cultures. The majority of past research in this area has occurred within America, with most assessment measures being created and validated among American samples (see Fig. 1). Future research should look to assess the ability of LS measures to transcend across cultures and specific groups. More specifically, further research is required to determine the differences between individualistic and collectivistic cultures and whether additional measures are required in order to overcome these differences. Additionally, there is a dearth of research which has examined LS as it pertains to those from specific populations, such as those with mental or physical disabilities, sufferers of disease or psychopathological conditions, and/or and those with exceptionally high LS and giftedness, for which there may be important domain and global LS differences. Overall, the extant literature points to LS as a key indicator of well-being, one that is integrally tied to emotional, behavioural, social, environmental, and psychological outcomes. 


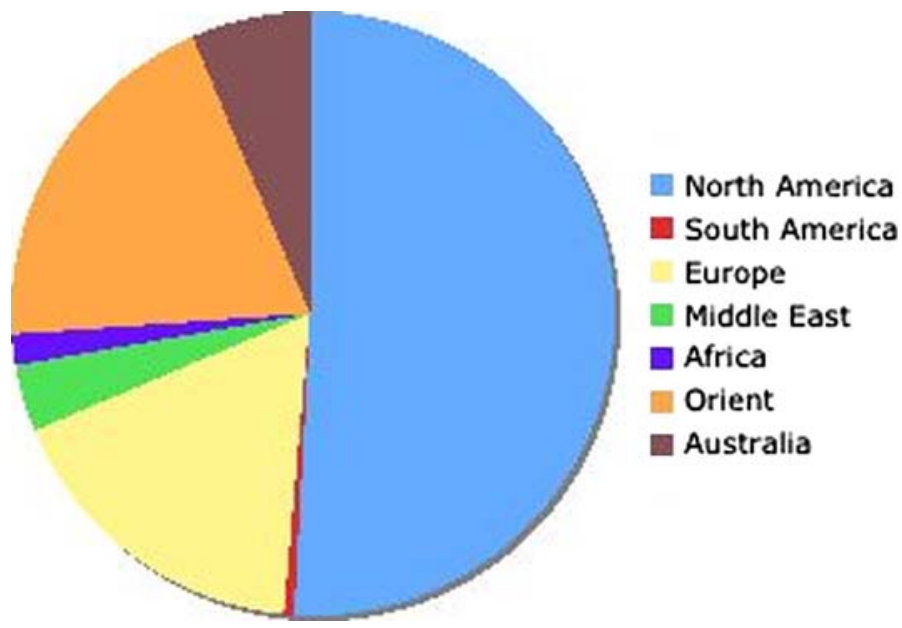

Fig. 1 Cultural distribution of youth life satisfaction literature

\section{Appendix}

Table 1 Youth life satisfaction

\begin{tabular}{|c|c|c|c|c|c|}
\hline Study & $n$ & Measure & Location & Major finding(s) & Study focus \\
\hline $\begin{array}{c}\text { Bradley and } \\
\text { Corwyn } \\
(2004)^{*}\end{array}$ & 310 & QOL & USA & $\begin{array}{l}\text { Marital status, self-efficacy } \\
\text { beliefs, and health status, } \\
\text { most consistent } \\
\text { predictors of LS of five } \\
\text { ethnic groups. }\end{array}$ & Acculturation \\
\hline $\begin{array}{l}\text { Hofman et al. } \\
\qquad(1982)^{*}\end{array}$ & 1,490 & SCS & Israel & Jews higher LS than Arabs. & Acculturation \\
\hline $\begin{array}{l}\text { Leung et al. } \\
\qquad(2006)^{*}\end{array}$ & 426 & 5-item & Australia & $\begin{array}{l}\text { Interaction effect between } \\
\text { ethnicity and LS. }\end{array}$ & Acculturation \\
\hline $\begin{array}{l}\text { Liebkind and } \\
\text { Jasinskaja- } \\
\text { Lahti }(2000)^{*}\end{array}$ & 588 & SWLS & Finland & $\begin{array}{l}\text { LS negatively related to } \\
\text { perceived discrimination } \\
\text { and positively related to } \\
\text { parental support and } \\
\text { length of residence. }\end{array}$ & Acculturation \\
\hline Neto $(1995)^{*}$ & 519 & SWLS & France & $\begin{array}{l}\text { LS negatively related to } \\
\text { perceived adaptation } \\
\text { problems, social anxiety, } \\
\text { marginalization, and } \\
\text { loneliness, and positively } \\
\text { related to LOC, good } \\
\text { health, religion, and } \\
\text { integration. }\end{array}$ & Acculturation \\
\hline
\end{tabular}


Table 1 continued

\begin{tabular}{|c|c|c|c|c|c|}
\hline Study & $n$ & Measure & Location & Major finding(s) & Study focus \\
\hline Neto $(2001)^{*}$ & 313 & SWLS & Portugal & $\begin{array}{l}\text { LS negatively related to } \\
\text { stressful experience } \\
\text { acculturation, perceived } \\
\text { discrimination, and } \\
\text { positively related to } \\
\text { mastery, gender, self- } \\
\text { esteem, and } \\
\text { neighbourhood. }\end{array}$ & Acculturation \\
\hline $\begin{array}{l}\text { Phinney and Ong } \\
(2002)^{*}\end{array}$ & 238 & SWLS & USA & $\begin{array}{l}\text { Adolescent-parent } \\
\text { disagreements negatively } \\
\text { related to LS. Ethnic } \\
\text { group did not moderate } \\
\text { the relationship. }\end{array}$ & Acculturation \\
\hline Sam $(1998)^{*}$ & 506 & SWLS & Norway & $\begin{array}{l}\text { LS positively related to } \\
\text { living in an ethnically } \\
\text { homogeneous } \\
\text { neighbourhood. }\end{array}$ & Acculturation \\
\hline Sam $(2000)^{*}$ & 506 & SWLS & Norway & $\begin{array}{l}\text { LS positively related to } \\
\text { ethnic identity, family } \\
\text { values, and social group } \\
\text { identity. }\end{array}$ & Acculturation \\
\hline $\begin{array}{l}\text { Ullman and Tatar } \\
(2001)^{*}\end{array}$ & 254 & SLSS & Israel & $\begin{array}{l}\text { Immigrant adolescents } \\
\text { lower LS than non- } \\
\text { immigrants. LS } \\
\text { positively related to } \\
\text { length of stay. }\end{array}$ & Acculturation \\
\hline $\begin{array}{l}\text { Verkuyten } \\
(1986)^{*}\end{array}$ & 261 & Cantril & Netherlands & $\begin{array}{l}\text { No support for distinction } \\
\text { between generalised LS } \\
\text { and hedonic affect. }\end{array}$ & Acculturation \\
\hline $\begin{array}{l}\text { Verkuyten } \\
(1989)^{*}\end{array}$ & 3,228 & Cantril & Netherlands & $\begin{array}{l}\text { Adolescents from ethnic } \\
\text { minority backgrounds } \\
\text { significantly lower LS } \\
\text { and happiness scores } \\
\text { than Dutch adolescents. }\end{array}$ & Acculturation \\
\hline $\begin{array}{l}\text { Virta et al. } \\
\qquad(2004)^{*}\end{array}$ & 840 & SWLS & $\begin{array}{l}\text { Turkey } \\
\text { Norway } \\
\text { Sweden }\end{array}$ & $\begin{array}{l}\text { LS negatively related to } \\
\text { perceived discrimination, } \\
\text { marginalization, and } \\
\text { positively related to } \\
\text { social identity, } \\
\text { integration. }\end{array}$ & Acculturation \\
\hline $\operatorname{Sam}(1994)^{* *}$ & 568 & 1-item & Norway & $\begin{array}{l}\text { Differences found between } \\
\text { the LS of immigrant and } \\
\text { Norwegian youths } \\
\text { among } 13 \text { year-old boys } \\
\text { and girls, and } 15 \text { year- } \\
\text { old girls. }\end{array}$ & Acculturation \\
\hline $\begin{array}{l}\text { Park and Peterson } \\
\qquad(2006 \mathrm{a})^{*}\end{array}$ & 680 & $\begin{array}{l}\text { Parental } \\
\quad \text { descriptions }\end{array}$ & USA & $\begin{array}{l}\text { Lower SES was associated } \\
\text { with reduced happiness. } \\
\text { Young children and only } \\
\text { children were somewhat } \\
\text { happier than oldest or } \\
\text { middle children. Hope, } \\
\text { love, and zest, related to } \\
\text { LS/happiness. }\end{array}$ & $\begin{array}{l}\text { Character } \\
\text { strengths }\end{array}$ \\
\hline
\end{tabular}


Table 1 continued

\begin{tabular}{|c|c|c|c|c|c|}
\hline Study & $n$ & Measure & Location & Major finding(s) & Study focus \\
\hline $\begin{array}{l}\text { Park and Peterson } \\
(2006 \mathrm{~b})^{*}\end{array}$ & 2,036 & SLSS & USA & $\begin{array}{l}\text { Strengths of hope, love, } \\
\text { gratitude, and zest, } \\
\text { associated with greater } \\
\text { LS. Parental self- } \\
\text { regulation was associated } \\
\text { with child LS. }\end{array}$ & $\begin{array}{l}\text { Character } \\
\text { strengths }\end{array}$ \\
\hline Liu et al. (2005)* & 872 & MSLSS & $\begin{array}{l}\text { China } \\
\text { USA }\end{array}$ & $\begin{array}{l}\text { Chinese students scored } \\
\text { higher on the dimensions } \\
\text { of Friends, School, and } \\
\text { general LS, than } \\
\text { American students. }\end{array}$ & $\begin{array}{r}\text { Cross-cultural } \\
\text { comparison }\end{array}$ \\
\hline $\begin{array}{l}\text { Park et al. } \\
\text { (2004a)* }\end{array}$ & 1,657 & $\begin{array}{l}\text { MSLSS } \\
\text { SLSS }\end{array}$ & $\begin{array}{l}\text { South } \\
\text { Korea } \\
\text { USA }\end{array}$ & $\begin{array}{l}\text { Psychometric support } \\
\text { provided for a Korean } \\
\text { version of the MSLSS. } \\
\text { Cross-cultural similarity } \\
\text { of the five-factor model } \\
\text { for students' LS } \\
\text { supported. }\end{array}$ & $\begin{array}{r}\text { Cross-cultural } \\
\text { comparison }\end{array}$ \\
\hline $\begin{array}{l}\text { Tanaka et al. } \\
(2005)^{*}\end{array}$ & 1,862 & 16-item & $\begin{array}{l}\text { Japan } \\
\text { Sweden }\end{array}$ & $\begin{array}{l}\text { Japanese lower LS than } \\
\text { Swedish. Japanese less } \\
\text { happy, more stress, } \\
\text { irritated, nervous and } \\
\text { angry. }\end{array}$ & $\begin{array}{r}\text { Cross-cultural } \\
\text { comparison }\end{array}$ \\
\hline $\begin{array}{l}\text { Park and Huebner } \\
(2005)^{* *}\end{array}$ & 1,059 & $\begin{array}{l}\text { MSLSS } \\
\text { SLSS }\end{array}$ & $\begin{array}{l}\text { USA } \\
\text { South } \\
\text { Korea }\end{array}$ & $\begin{array}{l}\text { Korean adolescents report } \\
\text { lower LS than American } \\
\text { adolescents. }\end{array}$ & $\begin{array}{r}\text { Cross-cultural } \\
\text { comparison }\end{array}$ \\
\hline $\begin{array}{l}\text { Constantine et al. } \\
(2006)^{*}\end{array}$ & 147 & SWLS & USA & $\begin{array}{l}\text { Adherence to Africentric } \\
\text { cultural values predictive } \\
\text { of higher self-esteem and } \\
\text { perceived social support, } \\
\text { which subsequently was } \\
\text { predictive of greater LS. }\end{array}$ & Cultural values \\
\hline Shek $(2005 a) *$ & $\begin{array}{l}\text { T1: } 229 \\
\text { T2: } 199\end{array}$ & SWLS & China & $\begin{array}{l}\text { LS positively related to } \\
\text { endorsement of Chinese } \\
\text { cultural beliefs about } \\
\text { adversity. }\end{array}$ & Cultural values \\
\hline Shek $(2004) * *$ & 1,519 & SWLS & China & $\begin{array}{l}\text { LS positively related to } \\
\text { endorsement of Chinese } \\
\text { cultural beliefs for both } \\
\text { economically and non- } \\
\text { economically } \\
\text { disadvantaged. }\end{array}$ & Cultural values \\
\hline $\begin{array}{l}\text { McCullough and } \\
\text { Huebner } \\
(2003)^{*}\end{array}$ & 160 & MSLSS & USA & $\begin{array}{l}\text { No differences in LS } \\
\text { among LD and NA } \\
\text { students. Both overall } \\
\text { positive levels of LS. }\end{array}$ & $\begin{array}{l}\text { Disabilities: } \\
\text { learning }\end{array}$ \\
\hline $\begin{array}{l}\text { Bramston et al. } \\
(2002)^{*}\end{array}$ & 132 & SLY & Australia & $\begin{array}{l}\text { LS related to level of } \\
\text { activity, friends, and } \\
\text { support. Disabled lower } \\
\text { use of community } \\
\text { facilities, social } \\
\text { belonging, and } \\
\text { empowerment. }\end{array}$ & $\begin{array}{l}\text { Disabilities: } \\
\text { mental }\end{array}$ \\
\hline
\end{tabular}


Table 1 continued

\begin{tabular}{|c|c|c|c|c|c|}
\hline Study & $n$ & Measure & Location & Major finding(s) & Study focus \\
\hline $\begin{array}{l}\text { Pretty et al. } \\
\qquad(2002)^{* *}\end{array}$ & 27 & QSLQ & Australia & $\begin{array}{l}\text { No significant differences } \\
\text { in overall LS between } \\
\text { adolescents with and } \\
\text { without an intellectual } \\
\text { disability determined. }\end{array}$ & $\begin{array}{l}\text { Disabilities: } \\
\text { mental }\end{array}$ \\
\hline $\begin{array}{l}\text { Brantley et al. } \\
\text { (2002)*** }\end{array}$ & 160 & MSLSS & USA & $\begin{array}{l}\text { Disabled lower friendship } \\
\text { satisfaction and higher } \\
\text { school experiences. } \\
\text { Higher school } \\
\text { satisfaction of self- } \\
\text { contained students. }\end{array}$ & $\begin{array}{l}\text { Disabilities: } \\
\text { mental }\end{array}$ \\
\hline $\begin{array}{l}\text { Gilman et al. } \\
\qquad(2004 a)^{*}\end{array}$ & 159 & MSLSS & USA & $\begin{array}{l}\text { D/HH youth reported lower } \\
\text { LS across most domains } \\
\text { than hearing peers. }\end{array}$ & $\begin{array}{c}\text { Disabilities: } \\
\text { physical }\end{array}$ \\
\hline Shek $(2005 \mathrm{e})^{*}$ & 3,017 & SWLS & China & $\begin{array}{l}\text { Economically } \\
\text { disadvantaged } \\
\text { adolescents more } \\
\text { hopeless, lower LS, } \\
\text { mastery, and self-esteem, } \\
\text { than without economic } \\
\text { disadvantage. }\end{array}$ & $\begin{array}{l}\text { Economic } \\
\text { disadvantage }\end{array}$ \\
\hline $\begin{array}{l}\text { Wilson et al. } \\
(1997)^{* *}\end{array}$ & 322 & 9-item & USA & $\begin{array}{l}\text { LS negatively related to } \\
\text { community size, } \\
\text { educational demands, } \\
\text { closeness to childhood } \\
\text { home, number of } \\
\text { children, and positively } \\
\text { related to marital status, } \\
\text { job/life goal attainment, } \\
\text { self-esteem. }\end{array}$ & $\begin{array}{l}\text { Economic } \\
\text { disadvantage }\end{array}$ \\
\hline Shek $(2003 b)^{*}$ & 229 & SWLS & China & $\begin{array}{l}\text { Increased economic stress } \\
\text { related to lower LS. }\end{array}$ & Economic stress \\
\hline Shek $(2005 \mathrm{c})^{*}$ & 1,519 & SWLS & China & $\begin{array}{l}\text { LS negatively related to } \\
\text { perceived economic } \\
\text { stress, future economic } \\
\text { worry, delinquent } \\
\text { behaviour, and substance } \\
\text { abuse. }\end{array}$ & Economic stress \\
\hline $\begin{array}{l}\text { Roberts et al. } \\
\qquad(2005)^{*}\end{array}$ & 4,175 & 1-item & USA & $\begin{array}{l}\text { Parent-child concordance } \\
\text { on indicators of mental } \\
\text { health low. Youths less } \\
\text { likely to report low LS } \\
\text { than caregivers. }\end{array}$ & $\begin{array}{l}\text { Emotional } \\
\text { disturbance }\end{array}$ \\
\hline $\begin{array}{l}\text { Griffin and } \\
\text { Huebner } \\
(2000)^{* * *}\end{array}$ & 98 & $\begin{array}{l}\text { SLSS } \\
\text { MSLSS }\end{array}$ & USA & $\begin{array}{l}\text { SED students lower levels of } \\
\text { LS than non-SED. SED } \\
\text { students formulate LS } \\
\text { judgments differently } \\
\text { than their non-SED peers. }\end{array}$ & $\begin{array}{l}\text { Emotional } \\
\text { disturbance }\end{array}$ \\
\hline
\end{tabular}


Table 1 continued

\begin{tabular}{|c|c|c|c|c|c|}
\hline Study & $n$ & Measure & Location & Major finding(s) & Study focus \\
\hline $\begin{array}{l}\text { Creed et al. } \\
\qquad(2003)^{*}\end{array}$ & $\begin{array}{l}\text { T1: } 309 \\
\text { T2: } 168\end{array}$ & 1 -item & Australia & $\begin{array}{l}\text { Full-time employed at T2 } \\
\text { highest LS, followed by } \\
\text { full-time students with } \\
\text { paid work, and those in } \\
\text { labour force without full- } \\
\text { time work (significantly } \\
\text { lower LS than other } \\
\text { groups). }\end{array}$ & Employment \\
\hline $\begin{array}{l}\text { Feather and } \\
\text { O'Brien } \\
(1986)^{* *}\end{array}$ & 4,931 & 10-item & Australia & $\begin{array}{l}\text { LS negatively related to } \\
\text { inability to find } \\
\text { employment after } \\
\text { leaving school, self- } \\
\text { reported perceptions of } \\
\text { reduced competence, } \\
\text { pleasantness, activity and } \\
\text { values, and increased } \\
\text { stress. }\end{array}$ & Employment \\
\hline $\begin{array}{l}\text { Homel and Burns } \\
(1989)^{* * *}\end{array}$ & 321 & CIS & Australia & $\begin{array}{l}\text { LS lower in high problem } \\
\text { neighbourhoods. } \\
\text { Children living in poorly } \\
\text { maintained houses had } \\
\text { lower LS. }\end{array}$ & $\begin{array}{l}\text { Environmental } \\
\text { quality }\end{array}$ \\
\hline $\begin{array}{l}\text { Heaven et al. } \\
(1996)^{*}\end{array}$ & 183 & SWLS & Australia & $\begin{array}{l}\text { LS, extraversion and self- } \\
\text { esteem positively } \\
\text { correlated with perceived } \\
\text { family functioning and } \\
\text { neuroticism, } \\
\text { psychoticism negatively } \\
\text { correlated. }\end{array}$ & $\begin{array}{l}\text { Family } \\
\text { functioning }\end{array}$ \\
\hline Shek $(1997 a)^{*}$ & 365 & SWLS & China & $\begin{array}{l}\text { LS negatively related to } \\
\text { mother and father } \\
\text { adolescent conflict and } \\
\text { poor family functioning. }\end{array}$ & $\begin{array}{l}\text { Family } \\
\quad \text { functioning }\end{array}$ \\
\hline Shek $(1997 b)^{*}$ & 429 & SWLS & China & $\begin{array}{l}\text { LS negatively related to } \\
\text { poor family functioning. }\end{array}$ & $\begin{array}{l}\text { Family } \\
\quad \text { functioning }\end{array}$ \\
\hline Shek 1997c)* & 429 & SWLS & China & $\begin{array}{l}\text { LS negatively related to } \\
\text { parent-adolescent } \\
\text { conflict. }\end{array}$ & $\begin{array}{l}\text { Family } \\
\text { functioning }\end{array}$ \\
\hline Shek $(1998 \mathrm{a})^{*}$ & $\begin{array}{l}\text { T1: } 429 \\
\text { T2: } 378\end{array}$ & SWLS & China & $\begin{array}{l}\text { Discrepancies in } \\
\text { perceptions of family } \\
\text { functioning between } \\
\text { adolescents and parents } \\
\text { negatively related to LS. }\end{array}$ & $\begin{array}{l}\text { Family } \\
\quad \text { functioning }\end{array}$ \\
\hline Shek $(1998 b)^{*}$ & $\begin{array}{l}\text { T1: } 429 \\
\text { T2: } 378\end{array}$ & SWLS & China & $\begin{array}{l}\text { LS negatively related to } \\
\text { parent-adolescent } \\
\text { conflict. Relationship } \\
\text { between adolescent- } \\
\text { parent conflict and well- } \\
\text { being bidirectional. }\end{array}$ & $\begin{array}{l}\text { Family } \\
\text { functioning }\end{array}$ \\
\hline
\end{tabular}


Table 1 continued

\begin{tabular}{|c|c|c|c|c|c|}
\hline Study & $n$ & Measure & Location & Major finding(s) & Study focus \\
\hline Shek (1999a)* & $\begin{array}{l}\text { T1: } 429 \\
\text { T2: } 378\end{array}$ & SWLS & China & $\begin{array}{l}\text { Individual LS concurrently } \\
\text { and longitudinally } \\
\text { related to parent and } \\
\text { child views of family } \\
\text { functioning. }\end{array}$ & $\begin{array}{l}\text { Family } \\
\text { functioning }\end{array}$ \\
\hline Shek $(2002 a)^{*}$ & 122 & SWLS & China & $\begin{array}{l}\text { LS negatively related to } \\
\text { poor family functioning } \\
\text { for adolescent girls. }\end{array}$ & $\begin{array}{l}\text { Family } \\
\text { functioning }\end{array}$ \\
\hline Shek $(2002 b)^{*}$ & 1,519 & SWLS & China & $\begin{array}{l}\text { LS negatively related to } \\
\text { poor family functioning } \\
\text { for both economically } \\
\text { and non-economically } \\
\text { disadvantaged. }\end{array}$ & $\begin{array}{l}\text { Family } \\
\text { functioning }\end{array}$ \\
\hline Shek $(2005 b)^{*}$ & $\begin{array}{l}\text { T1: } 229 \\
\text { T2: } 199\end{array}$ & SWLS & China & $\begin{array}{l}\text { Negative perceptions of } \\
\text { family functioning } \\
\text { related to lower LS. }\end{array}$ & $\begin{array}{l}\text { Family } \\
\text { functioning }\end{array}$ \\
\hline $\begin{array}{l}\text { Grossman and } \\
\quad \text { Rowat (1995)* }\end{array}$ & 244 & LS Index & Canada & $\begin{array}{l}\text { Perceived poor parental } \\
\text { relationships (but not } \\
\text { family status) associated } \\
\text { with low LS and sense of } \\
\text { future, and high anxiety } \\
\text { in adolescents of } \\
\text { divorced and married } \\
\text { parents. }\end{array}$ & Family structure \\
\hline $\begin{array}{l}\text { Zullig et al. } \\
\qquad(2005 \mathrm{~b})^{*}\end{array}$ & 5,021 & BMSLSS & USA & $\begin{array}{l}\text { LS negatively related to } \\
\text { living with other } \\
\text { relatives, non-relatives or } \\
\text { guardians, mother and } \\
\text { another adult, and father } \\
\text { only. }\end{array}$ & Family structure \\
\hline $\begin{array}{l}\text { Ash and Huebner } \\
\quad(1998)^{* * *}\end{array}$ & 122 & $\begin{array}{l}\text { MSLSS } \\
\text { SLSS }\end{array}$ & USA & $\begin{array}{l}\text { Global LS of gifted } \\
\text { students associated more } \\
\text { with school experience } \\
\text { than non-gifted. }\end{array}$ & Giftedness \\
\hline Hanrahan $(2005)^{*}$ & 34 & SWLS & Mexico & $\begin{array}{l}\text { Psychological skills } \\
\text { training programme } \\
\text { resulted in increases in } \\
\text { LS, global self-worth and } \\
\text { physical appearance self- } \\
\text { worth. }\end{array}$ & Goals/motivation \\
\hline $\begin{array}{l}\text { Hofer and } \\
\text { Chasiotis } \\
(2003)^{*}\end{array}$ & 295 & SWLS & Africa & $\begin{array}{l}\text { Lower education positively } \\
\text { related to LS. } \\
\text { Congruence between } \\
\text { implicit motives and self- } \\
\text { attributed goals related to } \\
\text { increased LS. }\end{array}$ & Goals/Motivation \\
\hline Lessing (1972)* & 168 & SWLS & USA & $\begin{array}{l}\text { Negative relationship } \\
\text { between LS and length of } \\
\text { cognitive future time } \\
\text { perspective for children } \\
\text { and positive for } \\
\text { adolescents. }\end{array}$ & Goals/motivation \\
\hline
\end{tabular}


Table 1 continued

\begin{tabular}{|c|c|c|c|c|c|}
\hline Study & $n$ & Measure & Location & Major finding(s) & Study focus \\
\hline $\begin{array}{l}\text { Gilman et al. } \\
(2006)^{*}\end{array}$ & 341 & SLSS & USA & $\begin{array}{l}\text { Youth reporting high (vs. } \\
\text { low and average) hope } \\
\text { had higher LS, personal } \\
\text { adjustment and less } \\
\text { emotional stress. }\end{array}$ & Hope \\
\hline $\begin{array}{l}\text { Valle et al. } \\
\qquad(2004)^{*}\end{array}$ & $\begin{array}{l}\text { S1: } 460 \\
\text { S2: } 531\end{array}$ & SLSS & USA & $\begin{array}{l}\text { LS positively related to } \\
\text { hope. Support for the } \\
\text { psychometric properties } \\
\text { of the CHS. }\end{array}$ & Hope \\
\hline $\begin{array}{l}\text { Roberts et al. } \\
\qquad(2002)^{*}\end{array}$ & $\begin{array}{l}\text { T1: } \\
\text { 4,175 } \\
\text { T2: } \\
3,136\end{array}$ & 1-item & USA & $\begin{array}{l}\text { Insomnia at baseline } \\
\text { increased subsequent risk } \\
\text { of psychological } \\
\text { dysfunction. }\end{array}$ & Insomnia \\
\hline $\begin{array}{l}\text { Suldo and } \\
\text { Huebner } \\
(2004 a)^{*}\end{array}$ & $\begin{array}{l}\text { T1: } \\
\text { 1,045 } \\
\text { T2: } 816\end{array}$ & SLSS & USA & $\begin{array}{l}\text { Adolescents with positive } \\
\text { LS less likely to develop } \\
\text { later externalizing } \\
\text { behaviours as a result of } \\
\text { stressful life events. }\end{array}$ & Life events \\
\hline $\begin{array}{l}\text { Ash and Huebner } \\
(2001)^{*}\end{array}$ & 152 & SLSS & USA & $\begin{array}{l}\text { LOC attributions mediated } \\
\text { the relationships between } \\
\text { negative life events and } \\
\text { chronic stressors and LS. }\end{array}$ & Life events \\
\hline $\begin{array}{l}\text { McCullough et al. } \\
(2000)^{*}\end{array}$ & 92 & SLSS & USA & $\begin{array}{l}\text { Positive daily events are } \\
\text { positively related to LS. }\end{array}$ & Life events \\
\hline $\begin{array}{l}\text { McKnight et al. } \\
(2002)^{*}\end{array}$ & 1,201 & SLSS & USA & $\begin{array}{l}\text { LS positively related to } \\
\text { extraversion and } \\
\text { negatively related to } \\
\text { neuroticism and stressful } \\
\text { life events. LS partial } \\
\text { mediator between } \\
\text { stressful life events and } \\
\text { internalizing behaviour. }\end{array}$ & Life events \\
\hline $\begin{array}{l}\text { Huebner et al. } \\
\quad(2000 \mathrm{a})^{*}\end{array}$ & 5,544 & BMSLSS & USA & $\begin{array}{l}\text { LS did not differ as a } \\
\text { function of gender, } \\
\text { grade, or race. The } \\
\text { majority reported } \\
\text { positive levels of LS. }\end{array}$ & $\begin{array}{l}\text { Life satisfaction: } \\
\text { levels }\end{array}$ \\
\hline Park $(2005)^{*}$ & 716 & $\begin{array}{l}\text { MSLSS } \\
\text { SLSS }\end{array}$ & $\begin{array}{l}\text { South } \\
\quad \text { Korea }\end{array}$ & $\begin{array}{l}\text { Global and domain LS } \\
\text { decreased from } \\
\text { childhood to } \\
\text { adolescence. }\end{array}$ & $\begin{array}{l}\text { Life satisfaction: } \\
\text { levels }\end{array}$ \\
\hline $\begin{array}{l}\text { Huebner et al. } \\
(2005)^{* * *}\end{array}$ & 2,502 & BMSLSS & USA & $\begin{array}{l}\text { Overall positive levels of } \\
\text { LS found. Demographics } \\
\text { not related to LS. }\end{array}$ & $\begin{array}{l}\text { Life satisfaction: } \\
\text { levels }\end{array}$ \\
\hline $\begin{array}{l}\text { Moore and } \\
\text { Schultz (1983)* }\end{array}$ & 99 & LS Scale & USA & $\begin{array}{l}\text { LS negatively related to } \\
\text { loneliness. }\end{array}$ & Loneliness \\
\hline Neto $(1993)^{* * *}$ & 217 & SWLS & Portugal & $\begin{array}{l}\text { Loneliness, social anxiety, } \\
\text { shyness, negatively } \\
\text { related with LS, self- } \\
\text { concept, happiness, } \\
\text { physical attractiveness, } \\
\text { positively related. }\end{array}$ & Loneliness \\
\hline
\end{tabular}


Table 1 continued

\begin{tabular}{|c|c|c|c|c|c|}
\hline Study & $n$ & Measure & Location & Major finding(s) & Study focus \\
\hline $\begin{array}{l}\text { Morojele and } \\
\text { Brook (2004)* }\end{array}$ & 103 & 11-item & Africa & $\begin{array}{l}\text { LS negatively related to } \\
\text { meaninglessness. }\end{array}$ & Meaninglessness \\
\hline Shek (1999c)* & $\begin{array}{l}\text { T1: } 429 \\
\text { T2: } 378\end{array}$ & SWLS & China & $\begin{array}{l}\text { Paternal qualities more } \\
\text { important than maternal } \\
\text { in predicting LS in boys, } \\
\text { and general } \\
\text { psychological health in } \\
\text { girls. }\end{array}$ & Parental qualities \\
\hline Shek $(2002 c)^{*}$ & 229 & SWLS & China & $\begin{array}{l}\text { Positive perceptions of } \\
\text { parental qualities } \\
\text { positively related to LS. }\end{array}$ & Parental qualities \\
\hline Shek (2005d)** & $\begin{array}{l}\text { T1: } 229 \\
\text { T2: } 199\end{array}$ & SWLS & China & $\begin{array}{l}\text { LS positively related to } \\
\text { positively perceived } \\
\text { parental qualities. }\end{array}$ & Parental qualities \\
\hline $\begin{array}{l}\text { Leung et al. } \\
\qquad(2004)^{*}\end{array}$ & 346 & MSLSS & China & $\begin{array}{l}\text { Perceived maternal concern } \\
\text { and academic } \\
\text { competence predicted LS } \\
\text { whereas maternal } \\
\text { restrictiveness did not. }\end{array}$ & Parental style \\
\hline Shek (1999b)* & $\begin{array}{l}\text { T1: } 429 \\
\text { T2: } 378\end{array}$ & SWLS & China & $\begin{array}{l}\text { Parenting styles and } \\
\text { specific parenting } \\
\text { behaviours bidirectional } \\
\text { relationship with LS. }\end{array}$ & Parental style \\
\hline Shek (2003a)* & $\begin{array}{l}\text { T1: } 229 \\
\text { T2: } 199\end{array}$ & SWLS & China & $\begin{array}{l}\text { Economically } \\
\text { disadvantaged lower LS } \\
\text { and more negative } \\
\text { perceptions of parenting } \\
\text { characteristics. }\end{array}$ & Parental style \\
\hline $\begin{array}{l}\text { Suldo and } \\
\text { Huebner } \\
(2004 b)^{*}\end{array}$ & 1,201 & SLSS & USA & $\begin{array}{l}\text { LS positively related to } \\
\text { authoritative parenting } \\
\text { styles. Parental social } \\
\text { support strongest } \\
\text { correlate. LS fully } \\
\text { mediated relationships } \\
\text { between social support } \\
\text { and adolescent problem } \\
\text { behaviour. }\end{array}$ & Parental style \\
\hline Ortman (1988)* & 16 & LS Scale & USA & $\begin{array}{l}\text { LS positively related to } \\
\text { feelings of control. }\end{array}$ & Perceived control \\
\hline $\begin{array}{l}\text { Smith et al. } \\
\qquad(1987)^{* *}\end{array}$ & 188 & PLSS & USA & $\begin{array}{l}\text { LS positively related to } \\
\text { perceived control at } \\
\text { school. }\end{array}$ & Perceived control \\
\hline $\begin{array}{l}\text { Adelman et al. } \\
\qquad(1989)^{* * *}\end{array}$ & 515 & PLSS & USA & $\begin{array}{l}\text { LS positively related to } \\
\text { perceived control at } \\
\text { school and negatively } \\
\text { related to depression and } \\
\text { age for children referred } \\
\text { for mental health } \\
\text { services. }\end{array}$ & Perceived control \\
\hline
\end{tabular}


Table 1 continued

\begin{tabular}{|c|c|c|c|c|c|}
\hline Study & $n$ & Measure & Location & Major finding(s) & Study focus \\
\hline $\begin{array}{l}\text { Gilman et al. } \\
(2005)^{*}\end{array}$ & 632 & $\begin{array}{l}\text { MSLSS } \\
\text { Croatia }\end{array}$ & USA & $\begin{array}{l}\text { Adaptive perfectionists } \\
\text { significantly higher LS } \\
\text { for both groups than } \\
\text { maladaptive and non- } \\
\text { perfectionists. }\end{array}$ & Perfectionism \\
\hline $\begin{array}{l}\text { Gilman and } \\
\text { Ashby } \\
(2003)^{* * *}\end{array}$ & 132 & MSLSS & USA & $\begin{array}{l}\text { Both perfectionist subtypes } \\
\text { significantly higher LS } \\
\text { than non-perfectionists. }\end{array}$ & Perfectionism \\
\hline Gilman $(2001)^{*}$ & 321 & MSLSS & USA & $\begin{array}{l}\text { High social interest } \\
\text { positively related to LS. } \\
\text { Higher numbers of SEAS } \\
\text { related to higher school } \\
\text { satisfaction. }\end{array}$ & Physical activity \\
\hline Maton $(1990)^{*}$ & $\begin{array}{l}\text { S1: } 152 \\
\text { S2: } 92\end{array}$ & SWLS & USA & $\begin{array}{l}\text { Meaningful instrumental } \\
\text { activity positively related } \\
\text { to LS. }\end{array}$ & Physical activity \\
\hline $\begin{array}{l}\text { Piko and } \\
\text { Keresztes } \\
(2006)^{*}\end{array}$ & 1,109 & SWLS & Hungary & $\begin{array}{l}\text { Active students better self- } \\
\text { perceived health, greater } \\
\text { fitness, lower depression, } \\
\text { and higher LS, than less } \\
\text { active students. }\end{array}$ & Physical activity \\
\hline $\begin{array}{l}\text { Valois et al. } \\
\text { (2004b)* }\end{array}$ & 4,758 & BMSLSS & USA & $\begin{array}{l}\text { LS negatively related to } \\
\text { not: playing on a sport } \\
\text { team run by school or } \\
\text { outside of school, doing } \\
\text { stretching exercises, } \\
\text { exercising for at least } \\
20 \text { min, doing exercises } \\
\text { to tone muscles. }\end{array}$ & Physical activity \\
\hline $\begin{array}{l}\text { Vilhjalmsson and } \\
\text { Thorlindsson } \\
\text { (1992)* }\end{array}$ & 1,131 & 1-item & Iceland & $\begin{array}{l}\text { LS positively related to } \\
\text { strenuous activity, sport } \\
\text { participation in clubs and } \\
\text { groups. }\end{array}$ & Physical activity \\
\hline $\begin{array}{l}\text { Honkala et al. } \\
(2006)^{*}\end{array}$ & 2,312 & 3-item & Kuwait & $\begin{array}{l}\text { All LS variables were } \\
\text { associated with more- } \\
\text { than-once-a-day } \\
\text { consumption of sugar } \\
\text { products. }\end{array}$ & Physical health \\
\hline $\begin{array}{l}\text { Langeveld et al. } \\
\text { (1999)* }\end{array}$ & 64 & OLH-Y & Norway & $\begin{array}{l}\text { Headache negatively } \\
\text { related to LS. Effect of } \\
\text { headache on LS is } \\
\text { greater with increased } \\
\text { experience of stress. }\end{array}$ & Physical health \\
\hline $\begin{array}{l}\text { Zullig et al. } \\
\text { (2005a)* }\end{array}$ & 4,914 & BMSLSS & USA & $\begin{array}{l}\text { LS negatively related to } \\
\text { poor self-rated health, } \\
\text { poor physical and mental } \\
\text { health, and activity } \\
\text { limitation. }\end{array}$ & Physical health \\
\hline $\begin{array}{l}\text { Langeveld et al. } \\
\qquad(1997)^{* *}\end{array}$ & 64 & OLH-Y & Norway & $\begin{array}{l}\text { Headache intensity and } \\
\text { frequency negatively } \\
\text { related to LS. }\end{array}$ & Physical health \\
\hline
\end{tabular}


Table 1 continued

\begin{tabular}{|c|c|c|c|c|c|}
\hline Study & $n$ & Measure & Location & Major finding(s) & Study focus \\
\hline $\begin{array}{l}\text { Guijarro et al. } \\
(1999)^{*}\end{array}$ & 135 & Health Survey & Ecuador & $\begin{array}{l}\text { Pregnant adolescents lower } \\
\text { LS, lower mother/father- } \\
\text { daughter communication, } \\
\text { happiness, and more } \\
\text { school and economic } \\
\text { difficulties than their } \\
\text { non-pregnant peers. }\end{array}$ & $\begin{array}{l}\text { Pregnancy/ } \\
\text { motherhood }\end{array}$ \\
\hline $\begin{array}{l}\text { Schilmoeller et al. } \\
\qquad(1991)^{*}\end{array}$ & 19 & 2-item & USA & $\begin{array}{l}\text { LS positively related to } \\
\text { perceived family support } \\
\text { and quality of } \\
\text { interactions within a } \\
\text { social network. }\end{array}$ & $\begin{array}{l}\text { Pregnancy/ } \\
\text { motherhood }\end{array}$ \\
\hline $\begin{array}{l}\text { Stevenson et al. } \\
\quad(1999)^{*}\end{array}$ & 110 & SWLS & USA & $\begin{array}{l}\text { Bidirectional support with } \\
\text { parents related to higher } \\
\text { mastery and LS and } \\
\text { lower depression and } \\
\text { anxiety. }\end{array}$ & $\begin{array}{l}\text { Pregnancy/ } \\
\text { motherhood }\end{array}$ \\
\hline $\begin{array}{l}\text { Unger and } \\
\text { Wandersman } \\
(1988)^{* *}\end{array}$ & 87 & 1-item & USA & $\begin{array}{l}\text { Both partner and family } \\
\text { support related to } \\
\text { increased LS for teenage } \\
\text { mothers. }\end{array}$ & $\begin{array}{l}\text { Pregnancy/ } \\
\text { motherhood }\end{array}$ \\
\hline Shek $(1998 \mathrm{c})^{*}$ & $\begin{array}{l}\text { T1: } 429 \\
\text { T2: } 378\end{array}$ & SWLS & China & $\begin{array}{l}\text { Lower LS at T1 related to } \\
\text { increased psychological } \\
\text { symptoms at } \mathrm{T} 2 \text {. }\end{array}$ & Psychopathology \\
\hline $\begin{array}{l}\text { Greenspoon and } \\
\text { Saklofske } \\
(2001)^{* * *}\end{array}$ & 407 & MSLSS & Canada & $\begin{array}{l}\text { Support for the validity of a } \\
\text { Dual-Factor System. } \\
\text { Classification of low } \\
\text { SWB-low PTH and high } \\
\text { SWB-high PTH groups. }\end{array}$ & Psychopathology \\
\hline $\begin{array}{l}\text { Brown et al. } \\
\qquad(2001)^{*}\end{array}$ & 4,514 & 1-item & USA & $\begin{array}{l}\text { Negative relationship } \\
\text { between LS and } \\
\text { worrying often about and } \\
\text { perceiving race relations } \\
\text { to be getting worse. }\end{array}$ & Race relations \\
\hline $\begin{array}{l}\text { Brown and } \\
\quad \text { Orthner (1990)* }\end{array}$ & 720 & 1-item & USA & $\begin{array}{l}\text { Negative relationship } \\
\text { between recent moves } \\
\text { and high number of } \\
\text { moves and LS for girls. }\end{array}$ & Relocation \\
\hline $\begin{array}{l}\text { Gilman and Barry } \\
(2003)^{*}\end{array}$ & 45 & MSLSS & USA & $\begin{array}{l}\text { Social desirability minimal } \\
\text { effect on LS. Satisfaction } \\
\text { ratings significantly } \\
\text { increased as a function of } \\
\text { time. }\end{array}$ & $\begin{array}{l}\text { Residential } \\
\text { treatment }\end{array}$ \\
\hline $\begin{array}{l}\text { Sastre and } \\
\text { Ferriere } \\
(2000)^{*}\end{array}$ & 100 & SWLS & France & $\begin{array}{l}\text { LS positively related to } \\
\text { living at home with } \\
\text { family. Females and } \\
\text { oldest participants had } \\
\text { lower LS. Four factors } \\
\text { account for variance in } \\
\text { LS: Family Life, Growth, } \\
\text { Work, and Self- } \\
\text { Affirmation. }\end{array}$ & $\begin{array}{r}\text { Residential } \\
\text { treatment }\end{array}$ \\
\hline
\end{tabular}


Table 1 continued

\begin{tabular}{|c|c|c|c|c|c|}
\hline Study & $n$ & Measure & Location & Major finding(s) & Study focus \\
\hline $\begin{array}{l}\text { Schiff et al. } \\
(2006)^{*}\end{array}$ & 103 & MSLSS & Israel & $\begin{array}{l}\text { LS positively related to care } \\
\text { worker-child } \\
\text { relationship, quality of } \\
\text { relationship with parents, } \\
\text { and frequency of parent- } \\
\text { child contact. }\end{array}$ & $\begin{array}{l}\text { Residential } \\
\text { treatment }\end{array}$ \\
\hline $\begin{array}{l}\text { Gilman and } \\
\text { Handwerk } \\
(2001)^{* * * *}\end{array}$ & 22 & MSLSS & USA & $\begin{array}{l}\text { LS significantly increased } \\
\text { over time in residential } \\
\text { treatment. }\end{array}$ & $\begin{array}{l}\text { Residential } \\
\text { treatment }\end{array}$ \\
\hline $\begin{array}{l}\text { Valois et al. } \\
\text { (2003)* }\end{array}$ & 4,758 & BMSLSS & USA & $\begin{array}{l}\text { LS negatively related to self } \\
\text { perceptions of } \\
\text { overweight, dieting, } \\
\text { taken diet pills, and/or } \\
\text { vomited/taken laxatives } \\
\text { to lose weight }\end{array}$ & $\begin{array}{l}\text { Risk-taking } \\
\text { behaviours: } \\
\text { dieting }\end{array}$ \\
\hline $\begin{array}{l}\text { Halvorsen and } \\
\text { Heyerdahl } \\
(2006)^{*}\end{array}$ & 55 & 1-item & Norway & $\begin{array}{l}\text { LS negatively correlated } \\
\text { with eating disorder } \\
\text { symptoms, psychiatric } \\
\text { problems, and self- } \\
\text { esteem. }\end{array}$ & $\begin{array}{l}\text { Risk-taking } \\
\text { behaviours: } \\
\text { dieting/ } \\
\text { anorexia } \\
\text { nervosa }\end{array}$ \\
\hline $\begin{array}{l}\text { Valois et al. } \\
\text { (2002)* }\end{array}$ & 4,758 & BMSLSS & USA & $\begin{array}{l}\text { LS negatively related to age } \\
\text { first intercourse, two or } \\
\text { more lifetime sexual } \\
\text { intercourse partners, no } \\
\text { contraception at last } \\
\text { intercourse, forcing sex/ } \\
\text { receiving forced sex, } \\
\text { beating/being beaten by } \\
\text { date. }\end{array}$ & $\begin{array}{l}\text { Risk-taking } \\
\text { behaviours: } \\
\text { Sexual }\end{array}$ \\
\hline $\begin{array}{l}\text { Braithwaite and } \\
\text { Devine (1993)* }\end{array}$ & 112 & Life 3 Scale & Australia & $\begin{array}{l}\text { Parental alcohol } \\
\text { dependency and family } \\
\text { disharmony have an } \\
\text { additive effect on LS. }\end{array}$ & $\begin{array}{l}\text { Risk-taking } \\
\text { behaviours: } \\
\text { substance } \\
\text { abuse }\end{array}$ \\
\hline $\begin{array}{l}\text { Donohue et al. } \\
(2003)^{*}\end{array}$ & 193 & $\begin{array}{l}\text { LSSPY } \\
1 \text {-item }\end{array}$ & USA & $\begin{array}{l}\text { LS related to Social } \\
\text { Satisfaction and } \\
\text { Satisfaction with } \\
\text { External Obligations for } \\
\text { drug abusing/conduct } \\
\text { disordered youth. }\end{array}$ & $\begin{array}{l}\text { Risk-taking } \\
\text { behaviours: } \\
\text { substance } \\
\text { abuse }\end{array}$ \\
\hline $\begin{array}{l}\text { Kuntsche and } \\
\text { Gmel (2004)* }\end{array}$ & 3,861 & 1-item & Switzerland & $\begin{array}{l}\text { Social and solitary risky } \\
\text { single occasion drinkers } \\
\text { (RSODs) lower LS than } \\
\text { social and solitary non- } \\
\text { RSODs. Solitary RSODs } \\
\text { lowest LS. }\end{array}$ & $\begin{array}{l}\text { Risk-taking } \\
\text { behaviours: } \\
\text { substance } \\
\text { abuse }\end{array}$ \\
\hline
\end{tabular}


Table 1 continued

\begin{tabular}{|c|c|c|c|c|c|}
\hline Study & $n$ & Measure & Location & Major finding(s) & Study focus \\
\hline Piko et al. (2005)* & 2,387 & SWLS & $\begin{array}{l}\text { Hungary } \\
\text { Poland } \\
\text { Turkey } \\
\text { USA }\end{array}$ & $\begin{array}{l}\text { LS directly/indirectly } \\
\text { related to smoking in all } \\
\text { countries except USA. } \\
\text { High LS, future- } \\
\text { orientedness, and social } \\
\text { comparison orientation, } \\
\text { related to reduced } \\
\text { smoking across } \\
\text { countries. Negative } \\
\text { relationship between LS } \\
\text { and hostility. }\end{array}$ & $\begin{array}{l}\text { Risk-taking } \\
\text { behaviours: } \\
\text { substance } \\
\text { abuse }\end{array}$ \\
\hline $\begin{array}{l}\text { Zullig et al. } \\
\qquad(2001)^{*}\end{array}$ & 5,032 & BMSLSS & USA & $\begin{array}{l}\text { LS negatively related to } \\
\text { smoking, chewing } \\
\text { tobacco, marijuana and } \\
\text { cocaine use, binge } \\
\text { drinking, injected drugs, } \\
\text { and steroids. }\end{array}$ & $\begin{array}{l}\text { Risk-taking } \\
\text { behaviours: } \\
\text { substance } \\
\text { abuse }\end{array}$ \\
\hline $\begin{array}{l}\text { Newcomb et al. } \\
\quad(1986)^{* * * *}\end{array}$ & $\begin{array}{l}\text { T1: } 896 \\
\text { T2: } 640\end{array}$ & 9-item & USA & $\begin{array}{l}\text { Alcohol use associated with } \\
\text { dissatisfaction with } \\
\text { perceived environment } \\
\text { (i.e. free time, relations } \\
\text { with parents, life in } \\
\text { general, opposite-sex } \\
\text { friends). }\end{array}$ & $\begin{array}{l}\text { Risk-taking } \\
\text { behaviours: } \\
\text { substance } \\
\text { abuse }\end{array}$ \\
\hline $\begin{array}{l}\text { Thatcher et al. } \\
\text { (2002)* }\end{array}$ & 4,565 & BMSLSS & USA & $\begin{array}{l}\text { Caucasian and African- } \\
\text { American males LS } \\
\text { significant moderating } \\
\text { variable associated with } \\
\text { attempted suicide. }\end{array}$ & $\begin{array}{l}\text { Risk-taking } \\
\text { behaviours: } \\
\text { suicide }\end{array}$ \\
\hline $\begin{array}{l}\text { Valois et al. } \\
\qquad(2004 a)^{*}\end{array}$ & 4,758 & BMSLSS & USA & $\begin{array}{l}\text { LS negatively related to } \\
\text { poor mental/physical } \\
\text { health, suicide } \\
\text { consideration, attempt, } \\
\text { attempt requiring } \\
\text { medical care. }\end{array}$ & $\begin{array}{l}\text { Risk-taking } \\
\text { behaviours: } \\
\text { suicide }\end{array}$ \\
\hline $\begin{array}{l}\text { MacDonald et al. } \\
(2005)^{*}\end{array}$ & 5,414 & MSLSS & USA & $\begin{array}{l}\text { Low LS associated with } \\
\text { increased violence and } \\
\text { risk-taking behaviour. }\end{array}$ & $\begin{array}{l}\text { Risk-taking } \\
\text { behaviours: } \\
\text { violence }\end{array}$ \\
\hline $\begin{array}{l}\text { Valois et al. } \\
\qquad(2001)^{*}\end{array}$ & 5,032 & BMSLSS & USA & $\begin{array}{l}\text { LS negatively related to } \\
\text { physical fighting at } \\
\text { school/requiring medical } \\
\text { treatment, carrying a } \\
\text { weapon/gun, carrying a } \\
\text { weapon at school, drink } \\
\text { driving, riding with drink } \\
\text { driver, property stolen/ } \\
\text { damaged at school, } \\
\text { feeling unsafe at/going } \\
\text { to/returning from school, } \\
\text { being injured/threatened } \\
\text { with a weapon. }\end{array}$ & $\begin{array}{l}\text { Risk-taking } \\
\text { behaviours: } \\
\text { violence }\end{array}$ \\
\hline
\end{tabular}


Table 1 continued

\begin{tabular}{|c|c|c|c|c|c|}
\hline Study & $n$ & Measure & Location & Major finding(s) & Study focus \\
\hline $\begin{array}{l}\text { Callahan et al. } \\
\qquad(2003)^{*}\end{array}$ & 190 & 8-item & USA & $\begin{array}{l}\text { Victimization related to } \\
\text { lower LS. }\end{array}$ & $\begin{array}{l}\text { Risk-taking } \\
\text { behaviours: } \\
\text { violence/ } \\
\text { victimization }\end{array}$ \\
\hline $\begin{array}{l}\text { Coker et al. } \\
\qquad(2000)^{*}\end{array}$ & 5,414 & BMSLSS & USA & $\begin{array}{l}\text { LS negatively associated } \\
\text { with SDV and forced-sex } \\
\text { victimization and } \\
\text { perpetration. }\end{array}$ & $\begin{array}{l}\text { Risk-taking } \\
\text { behaviours: } \\
\text { violence/ } \\
\text { victimization }\end{array}$ \\
\hline $\begin{array}{l}\text { Flouri and } \\
\text { Buchanan } \\
(2002)^{*}\end{array}$ & 1,224 & 1-item & UK & $\begin{array}{l}\text { Low father involvement } \\
\text { and peer victimization } \\
\text { significantly related to } \\
\text { low LS. Buffering effect } \\
\text { of father involvement in } \\
\text { that it protected children } \\
\text { from extreme } \\
\text { victimization. }\end{array}$ & $\begin{array}{l}\text { Risk-taking } \\
\text { behaviours: } \\
\text { violence/ } \\
\text { victimization }\end{array}$ \\
\hline $\begin{array}{l}\text { Chang et al. } \\
\qquad(2003)^{*}\end{array}$ & 189 & MSLSS & China & $\begin{array}{l}\text { Social self-concept } \\
\text { predictor of LS for } \\
\text { adolescents, academic } \\
\text { test scores predictor of } \\
\text { LS of children. } \\
\text { Adolescents lower LS } \\
\text { and self-concept and } \\
\text { higher in emotional } \\
\text { detachment than } \\
\text { children. }\end{array}$ & Self-concept \\
\hline $\begin{array}{l}\text { Dew and Huebner } \\
(1994)^{*}\end{array}$ & 222 & $\begin{array}{l}\text { SLSS } \\
\text { PLSS }\end{array}$ & USA & $\begin{array}{l}\text { Family-related self-concept } \\
\text { greater predictor of LS } \\
\text { than peer and academic } \\
\text { self-concept. LS } \\
\text { associated with SES. }\end{array}$ & Self-concept \\
\hline $\begin{array}{l}\text { Leung and Zhang } \\
\qquad(2000)^{*}\end{array}$ & 1,099 & $\begin{array}{l}\text { SWLS } \\
1 \text {-item }\end{array}$ & China & $\begin{array}{l}\text { Relationship construct has } \\
\text { greater influence on LS } \\
\text { than the self-concept } \\
\text { construct. Parent-child } \\
\text { relationship more } \\
\text { important than school- } \\
\text { child relationship. }\end{array}$ & Self-concept \\
\hline $\begin{array}{l}\text { Leung and Leung } \\
\qquad(1992)^{* * * *}\end{array}$ & 1,156 & SWLS & China & $\begin{array}{l}\text { Self-concept positively } \\
\text { correlated with LS. } \\
\text { Perceived relationship } \\
\text { with parents best } \\
\text { predictor of LS. }\end{array}$ & Self-concept \\
\hline $\begin{array}{l}\text { Terry and } \\
\text { Huebner } \\
(1995)^{* * *}\end{array}$ & 183 & SLSS & USA & $\begin{array}{l}\text { Parental relations strongest } \\
\text { predictor of LS for } \\
\text { children. }\end{array}$ & Self-concept \\
\hline $\begin{array}{l}\text { Pinquart et al. } \\
(2004)^{*}\end{array}$ & 593 & 9-item & Germany & $\begin{array}{l}\text { Higher self-efficacy before } \\
\text { German unification } \\
\text { associated with higher } \\
\text { LS after German } \\
\text { unification }\end{array}$ & Self-efficacy \\
\hline
\end{tabular}


Table 1 continued

\begin{tabular}{|c|c|c|c|c|c|}
\hline Study & $n$ & Measure & Location & Major finding(s) & Study focus \\
\hline $\begin{array}{l}\text { Oliva and Arranz } \\
(2005)^{*}\end{array}$ & 513 & 5 -item & Spain & $\begin{array}{l}\text { For girls, good relationship } \\
\text { with sibling positively } \\
\text { related to good } \\
\text { relationship with parents, } \\
\text { friends, and increased } \\
\text { self-esteem. }\end{array}$ & Siblings \\
\hline $\begin{array}{l}\text { Veenhoven and } \\
\text { Verkuyten } \\
(1989)^{*}\end{array}$ & 2,511 & Cantril & Netherlands & $\begin{array}{l}\text { Only children were not } \\
\text { found to report lower } \\
\text { levels of LS than their } \\
\text { peers with siblings. }\end{array}$ & Siblings \\
\hline $\begin{array}{l}\text { Burke and Weir } \\
(1978)^{*}\end{array}$ & 274 & 7-item & Canada & $\begin{array}{l}\text { Informal help by mothers, } \\
\text { fathers, and peers } \\
\text { positively related to LS. } \\
\text { Mothers help more } \\
\text { significant than fathers. }\end{array}$ & Social support \\
\hline $\begin{array}{l}\text { Greenberg et al. } \\
(1983)^{*}\end{array}$ & 213 & 1-item & USA & $\begin{array}{l}\text { Perceived quality of } \\
\text { relationships with parents } \\
\text { and peers significantly } \\
\text { related to LS. Quality of } \\
\text { attachment to parents } \\
\text { more significant than } \\
\text { peers. }\end{array}$ & Social support \\
\hline $\begin{array}{l}\text { Nickerson and } \\
\text { Nagle (2004)* }\end{array}$ & 303 & MSLSS & USA & $\begin{array}{l}\text { Parent and peer attachment } \\
\text { both significant } \\
\text { predictors of LS. }\end{array}$ & Social support \\
\hline $\begin{array}{l}\text { Vilhjalmsson } \\
(1994)^{*}\end{array}$ & 1,200 & 1-item & Iceland & $\begin{array}{l}\text { LS positively related to } \\
\text { positive assessment of } \\
\text { own health, support from } \\
\text { friends and parents, and } \\
\text { health related behaviour. }\end{array}$ & Social support \\
\hline $\begin{array}{l}\text { Wenk et al. } \\
\text { (1994)* }\end{array}$ & 672 & 10-item & USA & $\begin{array}{l}\text { LS positively related to } \\
\text { emotional involvement } \\
\text { of parents, feeling close } \\
\text { to father, love from } \\
\text { mother, and desire to } \\
\text { imitate mother. }\end{array}$ & Social support \\
\hline $\begin{array}{l}\text { Young et al. } \\
(1995)^{*}\end{array}$ & 640 & 5-item & USA & $\begin{array}{l}\text { Parental support positively } \\
\text { related to LS. Stronger } \\
\text { relationship between } \\
\text { perceived maternal } \\
\text { support and adolescent } \\
\text { LS. }\end{array}$ & Social support \\
\hline $\begin{array}{l}\text { Burke and Weir } \\
(1979)^{* * *}\end{array}$ & 274 & 7-item & Canada & $\begin{array}{l}\text { Domination- } \\
\text { disconfirmation and } \\
\text { distraction negatively } \\
\text { related to LS. Emotional } \\
\text { and concrete support } \\
\text { positively related to LS. }\end{array}$ & Social support \\
\hline $\operatorname{Man}(1991)^{* * *}$ & 1,906 & 26-item & China & $\begin{array}{l}\text { Parent orientation was a } \\
\text { better predictor of LS } \\
\text { than peer orientation. } \\
\text { Low peer orientation } \\
\text { related to higher LS. }\end{array}$ & Social support \\
\hline
\end{tabular}


Table 1 continued

\begin{tabular}{|c|c|c|c|c|c|}
\hline Study & $n$ & Measure & Location & Major finding(s) & Study focus \\
\hline $\begin{array}{l}\text { Zimmerman et al. } \\
(1995)^{* * * *}\end{array}$ & 254 & SWLS & USA & $\begin{array}{l}\text { LS positively related to } \\
\text { self-esteem and support } \\
\text { from parents and friends. } \\
\text { LS negatively related to } \\
\text { use of cigarettes, alcohol, } \\
\text { marijuana, and } \\
\text { depression and anxiety. }\end{array}$ & Social support \\
\hline $\begin{array}{l}\text { Huebner and Dew } \\
(1996)^{*}\end{array}$ & 266 & SLSS & USA & $\begin{array}{l}\text { Support for three-factor } \\
\text { structure of well-being; } \\
\text { i.e. positive affect, } \\
\text { negative affect, and LS. }\end{array}$ & $\begin{array}{l}\text { Subjective well- } \\
\text { being }\end{array}$ \\
\hline $\begin{array}{l}\text { Fogle et al. } \\
\qquad(2002)^{*}\end{array}$ & 160 & SLSS & USA & $\begin{array}{l}\text { Social self-efficacy } \\
\text { mediated relationship } \\
\text { between extraversion and } \\
\text { LS, but not between } \\
\text { neuroticism and LS. }\end{array}$ & Temperament \\
\hline Heaven $(1989)^{*}$ & $\begin{array}{l}\text { S1: } 99 \\
\text { S2: } 194\end{array}$ & SWLS & Australia & $\begin{array}{l}\text { Neuroticism and } \\
\text { psychoticism negatively } \\
\text { correlated with LS and } \\
\text { extraversion positively } \\
\text { correlated. }\end{array}$ & Temperament \\
\hline $\begin{array}{l}\text { Rigby and } \\
\text { Huebner } \\
(2005)^{*}\end{array}$ & 211 & SLSS & USA & $\begin{array}{l}\text { LS positively related to } \\
\text { emotional stability. } \\
\text { Causal attributions for } \\
\text { good events mediated } \\
\text { the relationship between } \\
\text { LS and emotional } \\
\text { stability. }\end{array}$ & Temperament \\
\hline $\begin{array}{l}\text { Huebner } \\
\qquad(1991 \mathrm{a}) * * *\end{array}$ & 79 & SLSS & USA & $\begin{array}{l}\text { LS positively related to } \\
\text { self-esteem, LOC, and } \\
\text { extraversion and } \\
\text { negatively related to } \\
\text { anxiety and neuroticism. }\end{array}$ & Temperament \\
\hline $\begin{array}{l}\text { Casas et al. } \\
\text { (2004)* }\end{array}$ & 968 & 8-item & Spain & $\begin{array}{l}\text { LS positively correlated } \\
\text { with non-materialistic } \\
\text { values. LS mediator } \\
\text { between behavioural } \\
\text { intentions and values. }\end{array}$ & Values \\
\hline $\begin{array}{l}\text { Linley et al. } \\
\text { (2004, } \\
\text { unpublished)** }\end{array}$ & 218 & SLSS & UK & $\begin{array}{l}\text { Intrinsic values associated } \\
\text { with increased LS. }\end{array}$ & Values \\
\hline $\begin{array}{l}\text { Gilman and } \\
\text { Huebner } \\
(2006)^{*}\end{array}$ & 485 & SLSS & USA & $\begin{array}{l}\text { High LS is associated with } \\
\text { higher adaptive and } \\
\text { interpersonal } \\
\text { functioning, lower social } \\
\text { stress, and better } \\
\text { attitudes towards } \\
\text { teachers and less } \\
\text { psychological } \\
\text { symptoms. }\end{array}$ & Very high LS \\
\hline
\end{tabular}


Table 1 continued

\begin{tabular}{|c|c|c|c|c|c|}
\hline Study & $n$ & Measure & Location & Major finding(s) & Study focus \\
\hline $\begin{array}{l}\text { Suldo and } \\
\text { Huebner } \\
(2006)^{*}\end{array}$ & 698 & SLSS & USA & $\begin{array}{l}\text { Positively related to } \\
\text { increased social, } \\
\text { emotional, and academic, } \\
\text { competence/self- } \\
\text { efficacy. High LS lowest } \\
\text { psychopathology, highest } \\
\text { social support, low } \\
\text { internalizing/ } \\
\text { externalizing behaviour. }\end{array}$ & Very high LS \\
\hline
\end{tabular}

* First literature search strategy

** Second literature search strategy

*** Third literature search strategy

BMSLSS: Brief Multidimensional Students' Life Satisfaction Scale (Seligson et al. 2003)

Cantril: Cantril's single-item measure of LS (Cantril 1965)

CIS: Child Interview Schedule

Life 3 Scale: Life 3 Scale (Andrews and Withey 1976)

LS Index: Life Satisfaction Index (Wood et al. 1969)

LS Scale: Unknown $n$-item LS measure

LSSPY: Life Satisfaction Scale for Problem Youth (Donohue et al. 2003)

MSLSS: Multidimensional Students' Life Satisfaction Scale (Huebner 1994)

$n$-item: Number of LS items of the scale used

PAHO: Pan American Health Organization/Kellogg survey

Parental: Parents provided open-ended descriptions of their child

\section{Description}

PLSS: Perceived Life Satisfaction Scale (Adelman et al. 1989)

QLH-Y: Quality of Life Headache-Youth questionnaire

QOL: Quality of Life questionnaire

QSLQ: Quality of Student Life Questionnaire

S1/S2: Sample 1/Sample 2

SCS: Self Concept Scale

SLSS: Students' Life Satisfaction Scale (Huebner 1991c)

SWLS: Satisfaction With Life Scale (Diener et al. 1985)

T1/T2: Time 1/Time 2

\section{References}

Accordino, D. B., Accordino, M. P., \& Slaney, R. B. (1999). An investigation of perfectionism, mental health, achievement, and achievement motivation in adolescents. Psychology in the Schools, 37, 535545.

Adelman, H. S., Taylor, L., \& Nelson, P. (1989). Minors' dissatisfaction with their life circumstances. Child Psychiatry and Human Development, 20, 135-147.

Amato, P. R. (1994). Father-child relations, mother-child relations, and offspring psychological well-being in early adulthood. Journal of Marriage and Family, 56, 1031-1042.

American Psychiatric Association. (1994). Diagnostic and statistical manual of mental disorders (4th ed.). Washington, DC: Author.

Anderson, G., \& Arsenault, N. (1998). Fundamentals of educational research. Routledge: Taylor \& Francis Group. 
Andrews, F. M., \& Withey, S. B. (1976). Social indicators of well-being: American's perceptions of life quality. New York, NY: Plenum.

Argyle, M., \& Lu, L. (1990a). Happiness and social skills. Personality and Individual Differences, 11, 1255-1261.

Argyle, M., \& Lu, L. (1990b). The happiness of extraverts. Personality and Individual Differences, 11, 1011-1017.

Aristotle. (1925). The Nicomachean ethics. New York, NY: Oxford University Press.

Ash, C., \& Huebner, E. S. (1998). Life satisfaction reports of gifted middle-school children. School Psychology Quarterly, 13, 310-321.

Ash, C., \& Huebner, E. S. (2001). Environmental events and life satisfaction reports of adolescents: A test of cognitive mediation. School Psychology International, 22, 320-336.

Asher, S. R., \& Hopmeyer, A. (1997). Loneliness in childhood. In G. G. Bear, K. M. Minke \& A. Thomas (Eds.), Children's needs II: Development, problems and alternatives (pp. 279-292). Bethesda, MD: National Association of School Psychologists.

Blom-Hoffman, J., Edwards George, J. B., \& Franko, D. L. (2006). Childhood overweight. In G. G. Bear \& K. M. Minke (Eds.), Children's needs III: Development, prevention and intervention (pp. 989-1000). Bethesda, MD: National Association of School Psychologists.

Bradley, R. H., \& Corwyn, R. F. (2004). Life satisfaction among European American, African American, Chinese American, Mexican American, and Dominican American adolescents. International Journal of Behavioral Development, 28, 385-400.

Braithwaite, V., \& Devine, C. (1993). Life satisfaction and adjustment of children of alcoholics: The effects of parental drinking, family disorganization and survival roles. British Journal of Clinical Psychology, $32,417-429$.

Bramston, P., Bruggerman, K., \& Pretty, G. (2002). Community perspectives and subjective quality of life. International Journal of Disability, Development and Education, 49, 385-397.

Brantley, A., Huebner, E. S., \& Nagle, R. J. (2002). Multidimensional life satisfaction reports of adolescents with mild mental disabilities. Mental Retardation, 40, 321-329.

Brown, A. C., \& Orthner, D. K. (1990). Relocation and personal well-being among early adolescents. Journal of Early Adolescence, 10, 366-381.

Brown, T. N., Wallace, J. M., \& Williams, D. R. (2001). Race-related correlates of young adults' subjective well-being. Social Indicators Research, 53, 97-116.

Burke, R. J., \& Weir, T. (1978). Benefits to adolescent of informal helping relationships with their parents and peers. Psychological Reports, 42, 1175-1184.

Burke, R. J., \& Weir, T. (1979). Helping responses of parents and peers and adolescent well-being. The Journal of Psychology, 102, 49-62.

Callahan, M. R., Tolman, R. M., \& Saunders, D. G. (2003). Adolescent dating violence victimization and psychological well-being. Journal of Adolescent Research, 18, 664-681.

Cantril, H. (1965). The patterns of human concern. New Brunswick, NJ: Rutgers University Press.

Casas, F., Gonzalez, M., Figuer, C., \& Coenders, G. (2004). Subjective well-being, values and goal achievement: The case of planned versus by chance searches on the Internet. Social Indicators Research, 66, 123-141.

Chang, L., McBride-Chang, C., Stewart, S. M., \& Au, E. (2003). Life satisfaction, self-concept, and family relations in Chinese adolescents and children. International Journal of Behavioral Development, 27, $182-189$.

Coker, A. L., McKeown, R. E., Sanderson, M., Davis, K. E., Valois, R. F., \& Huebner, E. S. (2000). Severe dating violence and quality of life among South Carolina high school students. American Journal of Preventive Medicine, 19, 220-227.

Constantine, M. G., Alleyne, V. L., Wallace, B. C., \& Franklin-Jackson, D. C. (2006). Africentric cultural values: Their relation to positive mental health in African American adolescent girls. Journal of Black Psychology, 32, 141-154.

Costa, P. T., Jr., \& McCrae, R. R. (1980). Influence of extraversion and neuroticism on subjective wellbeing: Happy and unhappy people. Journal of Personality and Social Psychology, 38, 668-678.

Cowen, E. L. (1991). In pursuit of wellness. American Psychologist, 46, 404-408.

Creed, P. A., Muller, J., \& Patton, W. (2003). Leaving high school: The influence and consequences for psychological well-being and career-related confidence. Journal of Adolescence, 26, 295-311.

Deci, E. L., \& Ryan, R. M. (2000). The 'what' and 'why' of goal pursuits: Human needs and the selfdetermination of behavior. Psychological Inquiry, 11, 227-268.

Demo, D. H., \& Acock, A. C. (1996). Family structure, family process, and adolescent well-being. Journal of Research on Adolescence, 6, 457-488. 
DeNeve, K. M., \& Cooper, H. (1998). The happy personality: A meta-analysis of 137 personality traits and subjective well-being. Psychological Bulletin, 124, 197-229.

Dew, T., \& Huebner, E. S. (1994). Adolescents' perceived quality of life: An exploratory investigation. Journal of School Psychology, 33, 185-199.

Diener, E. (1984). Subjective well-being. Psychological Bulletin, 95, 542-575.

Diener, E. (1994). Assessing subjective well-being: Progress and opportunities. Social Indicators Research, $31,103-157$.

Diener, E. (1996). Traits can be powerful, but are not enough: Lessons from subjective well-being. Journal of Research in Personality, 30, 389-399.

Diener, E., \& Diener, M. (1995). Cross-cultural correlates of life satisfaction and self-esteem. Journal of Personality and Social Psychology, 68, 653-663.

Diener, E., \& Diener, C. (1996). Most people are happy. Psychological Science, 7, 181-185.

Diener, E., Emmons, R. A., Larsen, R. J., \& Griffin, S. (1985). The satisfaction with life scale. Journal of Personality Assessment, 49, 71-75.

Diener, E., Suh, E. M., Lucas, R. E., \& Smith, H. L. (1999). Subjective well-being three decades of progress. Psychological Bulletin, 125, 276-302.

Diener, E., Suh, E. M., \& Oishi, S. (1997). Recent findings on subjective well-being. Indian Journal of Clinical Psychology, 24, 25-41.

Donohue, B., Teichner, G., Azrin, N., Weintraub, N., Crum, T. A., Murphy, L., et al. (2003). Initial reliability and validity of the Life Satisfaction Scale for Problem Youth in a sample of drug abusing and conduct disordered youth. Journal of Child \& Family Studies, 12, 453-464.

Due, P., Holstein, B. E., Ito, H., \& Groth, M. V. (1991). Diet and health behaviour in Danish children aged 11-15 years. Tandlaegernes Tidsskr, 6, 232-237.

Emmons, R. A. (1986). Personal strivings: An approach to personality and subjective well-being. Journal of Personality and Social Psychology, 51, 1058-1068.

Emmons, R. A., \& Diener, E. (1985). Personality correlates of subjective well-being. Personality and Social Psychology Bulletin, 11, 89-97.

Emmons, R. A., \& Diener, E. (1986). A goal-affect analysis of everyday situational choices. Journal of Research in Personality, 20, 309-326.

Enns, M. W., \& Cox, B. J. (1999). Perfectionism and depression symptom severity in major depressive disorder. Behaviour Research and Therapy, 37, 783-794.

Eysenck, H. J., \& Eysenck, S. B. G. (1975). Manual of the Eysenck Personality Questionnaire. London: Hodder \& Stoughton Educational.

Fabricatore, A. N., \& Handal, P. J. (2000). Personal spirituality as a moderator of the relationship between stressors and subjective well-being. Journal of Psychology and Theology, 28, 221-228.

Feather, N. T., \& O’Brien, G. E. (1986). A longitudinal study of the effects of employment and unemployment on school-leavers. Journal of Occupational Psychology, 59, 121-144.

Flouri, E., \& Buchanan, A. (2002). Life satisfaction in teenage boys: The moderating role of father involvement and bullying. Aggressive Behavior, 28, 126-133.

Fogle, L. M., Huebner, E. S., \& Laughlin, J. E. (2002). The relationship between temperament and life satisfaction in early adolescence: Cognitive and behavioral mediation models. Journal of Happiness Studies, 3, 373-392.

Forman, S. G., Bry, B. H., \& Urga, P. A. (2006). Substance abuse. In G. G. Bear \& K. M. Minke (Eds.), Children's needs III: Development, prevention, and intervention (pp. 1011-1023). Bethesda: National Association of School Psychologists.

Funk, B. A., Huebner, E. S., \& Valois, R. F. (2006). Reliability and validity of a brief life satisfaction scale with a high school sample. Journal of Happiness Studies, 7, 41-54.

Gilman, R. (2001). The relationship between life satisfaction, social interest, and frequency of extracurricular activities among adolescent students. Journal of Youth and Adolescence, 30, 749-767.

Gilman, R., \& Ashby, J. S. (2003). A first study of perfectionism and multidimensional life satisfaction among adolescents. Journal of Early Adolescence, 23, 218-235.

Gilman, R., \& Ashby, J. S. (2006). Perfectionism. In G. G. Bear \& K. M. Minke (Eds.), Children's needs III: Development, prevention and intervention (pp. 303-312). Bethesda, MD: National Association of School Psychologists.

Gilman, R., Ashby, J. S., Sverko, D., Florell, D., \& Varjas, K. (2005). The relationship between perfectionism and multidimensional life satisfaction among Croatian and American youth. Personality and Individual Differences, 39, 155-166.

Gilman, R., \& Barry, J. (2003). Life satisfaction and social desirability among adolescents in a residential treatment setting: Changes across time. Residential Treatment for Children and Youth, 21, 19-42. 
Gilman, R., Dooley, J., \& Florell, D. (2006). Relative levels of hope and their relationship with academic and psychological indicators among adolescents. Journal of Social and Clinical Psychology, 25, 166178.

Gilman, R., Easterbrooks, S. R., \& Frey, M. (2004a). A preliminary study of multidimensional life satisfaction among deaf/hard of hearing youth across environmental settings. Social Indicators Research, $66,143-164$.

Gilman, R., \& Handwerk, M. L. (2001). Changes in life satisfaction as a function of stay in a residential setting. Residential Treatment for Children and Youth, 18, 47-65.

Gilman, R., \& Huebner, E. S. (1997). Children's reports of their life satisfaction: Convergence across raters, time and response format. School Psychology International, 18, 229-243.

Gilman, R., \& Huebner, E. S. (2000). Review of life satisfaction measures for adolescents. Behaviour Change, 17, 178-195.

Gilman, R., \& Huebner, E. S. (2003). A review of life satisfaction research with children and adolescents. School Psychology Quarterly, 18, 192-205.

Gilman, R., \& Huebner, E. S. (2006). Characteristics of adolescents who report very high life satisfaction. Journal of Youth and Adolescence, 35, 311-319.

Gilman, R., Huebner, E. S., \& Laughlin, J. E. (2000). A first study of the Multidimensional Students' Life Satisfaction Scale with adolescents. Social Indicators Research, 52, 135-160.

Gilman, R., Meyers, J., \& Perez, L. (2004b). Structured extracurricular activities among adolescents: Findings and implications for school psychologists. Psychology in the Schools, 41, 31-41.

Greenberg, M. T., Siegel, J. M., \& Leitch, C. J. (1983). The nature and importance of attachment relationships to parents and peers during adolescence. Journal of Youth and Adolescence, 12, 373-386.

Greene, S. M., Anderson, E. R., Doyle, E. A., \& Riedelbach, H. (2006). Divorce. In G. G. Bear \& K. M. Minke (Eds.), Children's needs III: Development, prevention and intervention (pp. 745-757). Bethesda, MD: National Association of School Psychologists.

Greenspoon, P. J., \& Saklofske, D. H. (1997). Validity and reliability of the Multidimensional Students' Life Satisfaction Scale with Canadian children. Journal of Psychoeducational Assessment, 15, 138-155.

Greenspoon, P. J., \& Saklofske, D. H. (2001). Toward an integration of subjective well-being and psychopathology. Social Indicators Research, 54, 81-108.

Griffin, M. D., \& Huebner, E. S. (2000). Multidimensional life satisfaction reports of middle school students with serious emotional disturbance. Journal of Psychoeducational Assessment, 18, 111-124.

Grossman, M., \& Rowat, K. M. (1995). Parental relationships, coping strategies, received support and wellbeing in adolescents of separated or divorced and married parents. Research in Nursing \& Health, 18, 249-261.

Guijarro, S., Naranjo, J., Padilla, M., Gutierez, R., Lammers, C., \& Blum, R. W. (1999). Family risk factors associated with adolescent pregnancy: Study of a group of adolescent girls and their families in Ecuador. Journal of Adolescent Health, 25, 166-172.

Halvorsen, I., \& Heyerdahl, S. (2006). Girls with anorexia nervosa as young adults: Personality, self-esteem, and life satisfaction. International Journal of Eating Disorders, 39, 285-293.

Hanrahan, S. J. (2005). Using psychological skills training from sport psychology to enhance the life satisfaction of adolescent Mexican Orphans. Athletic Insight: Online Journal of Sport Psychology, 7, no pagination specified. Accessed June 14, 2006 from http://www.athleticinsight.com.

Headey, B., Kelley, J., \& Wearing, A. (1993). Dimensions of mental health: Life satisfaction, positive affect, anxiety, and depression. Social Indicators Research, 29, 63-82.

Headey, B., \& Wearing, A. (1989). Personality, life events, and subjective well-being: Toward a dynamic equilibrium model. Journal of Personality and Social Psychology, 57, 731-739.

Heaven, P. C. L. (1989). Extraversion, neuroticism and satisfaction with life among adolescents. Personality and Individual Differences, 10, 489-492.

Heaven, P., Searight, H. R., Chastain, J., \& Skitka, L. J. (1996). The relationship between perceived family health and personality functioning among Australian adolescents. American Journal of Family Therapy, 24, 358-366.

Hofer, J., \& Chasiotis, A. (2003). Congruence of life goals and implicit motives as predictors of life satisfaction: Cross-cultural implications of a study of Zambian male adolescents. Motivation and Emotion, 27, 251-272.

Hofman, J. E., Beit-Hallahmi, B., \& Hertz-Lazarowitz, R. (1982). Self-concept of Jewish and Arab adolescents in Israel. Journal of Personality and Social Psychology, 43, 786-792.

Holstein, B. E., Ito, H., \& Due, P. (1990). Physical exercise among school children. A nation-wide sociomedical study of 1, 671 children 11-15 years of age. Ugeskr Laeger, 152, 2721-2727.

Homel, R., \& Burns, A. (1989). Environmental quality and the well-being of children. Social Indicators Research, 21, 133-158. 
Honkala, S., Hondala, E., \& Al-Sahli, N. (2006). Consumption of sugar products and associated life- and school-satisfaction and self-esteem factors among schoolchildren in Kuwait. Acta Odontologica Scandinavica, 64, 79-88.

Huebner, E. S. (1991a). Correlates of life satisfaction in children. School Psychology Quarterly, 6, $103-111$.

Huebner, E. S. (1991b). Further validation of the Students' Life Satisfaction Scale: The independence of satisfaction and affect ratings. Journal of Psychoeducational Assessment, 9, 363-368.

Huebner, E. S. (1991c). Initial development of the Students' Life Satisfaction Scale. School Psychology International, 12, 231-240.

Huebner, E. S. (1994). Preliminary development and validation of a multidimensional life satisfaction scale for children. Psychological Assessment, 6, 149-158.

Huebner, E. S. (1995). The Students' Life Satisfaction Scale: An assessment of psychometric properties with black and white elementary school students. Social Indicators Research, 34, 315-323.

Huebner, E. S. (2004). Research on assessment of life satisfaction of children and adolescents. Social Indicators Research, 66, 3-33.

Huebner, E. S., \& Alderman, G. L. (1993). Convergent and discriminant validation of a children's life satisfaction scale: Its relationship to self- and teacher-reported psychological problems and school functioning. Social Indicators Research, 30, 71-82.

Huebner, E. S., Brantley, A., Nagle, R., \& Valois, R. F. (2002). Correspondence between parent and adolescent ratings of life satisfaction for adolescents with and without mental disabilities. Journal of Psychoeducational Assessment, 20, 20-29.

Huebner, E. S., \& Dew, T. (1993a). Is life satisfaction multidimensional? The factor structure of the Perceived Life Satisfaction Scale. Journal of Psychoeducational Assessment, 11, 345-350.

Huebner, E. S., \& Dew, T. (1993b). Validity of the Perceived Life Satisfaction Scale. School Psychology International, 14, 355-360.

Huebner, E. S., \& Dew, T. (1996). The interrelationships of positive affect, negative affect and life satisfaction, in an adolescent sample. Social Indicators Research, 38, 129-137.

Huebner, E. S., Drane, J. W., \& Valois, R. F. (2000a). Levels and demographic correlates of adolescent life satisfaction reports. School Psychology International, 21, 281-292.

Huebner, E. S., Funk, B. A., \& Gilman, R. (2000b). Cross-sectional and longitudinal psychosocial correlates of adolescent life satisfaction reports. Canadian Journal of School Psychology, 16, 53-64.

Huebner, E. S., Laughlin, J. E., Ash, C., \& Gilman, R. (1998). Further validation of the Multidimensional Students' Life Satisfaction Scale. Journal of Psychoeducational Assessment, 16, 118-134.

Huebner, E. S., Suldo, S. M., Smith, L. C., \& McKnight, C. G. (2004a). Life satisfaction in children and youth: Empirical foundations and implications for school psychologists. Psychology in the Schools, 41, 81-93.

Huebner, E. S., Suldo, S. M., Valois, R. F., Drane, J. W., \& Zullig, K. J. (2004b). Brief Multidimensional Students' Life Satisfaction Scale: Sex, race, and grade effects in a high school sample. Psychological Reports, 94, 351-356.

Huebner, E. S., Valois, R. F., Paxton, R. J., \& Drane, J. W. (2005). Middle school students' perceptions of quality of life. Journal of Happiness Studies, 6, 15-24.

Jaffee, S., Caspi, A., Moffitt, T. E., Belsky, J., \& Silva, P. (2001). Why are children born to teen mothers at risk for adverse outcomes in young adulthood? Results from a 20-yr longitudinal study. Development and Psychopathology, 12, 377-397.

Kamman, R., Farry, M., \& Herbison, P. (1984). The analysis and measurement of happiness as a sense of well-being. Social Indicators Research, 15, 91-116.

Kasser, T. (2004). The good life or the goods life? Positive psychology and personal well-being in the culture of consumption. In P. A. Linley \& S. Joseph (Eds.), Positive psychology in practice (pp. 5567). Holboken, NJ: Wiley.

Kuntsche, E. N., \& Gmel, G. (2004). Emotional wellbeing and violence among social and solitary risky single occasion drinkers in adolescence. Addiction, 99, 331-339.

Langeveld, J. H., Koot, H. M., Loonen, M. C., Hazebroek-Kampschreur, A. A. J. M., \& Passchier, J. (1996). A quality of life instrument for adolescents with chronic headache. Cephalalgia, 16, 183-196.

Langeveld, J. H., Koot, H. M., \& Passchier, J. (1997). Headache intensity and quality of life in adolescents: How are changes in headache intensity in adolescents related to changes in experienced quality of life? Headache: The Journal of Head and Face Pain, 37, 37-42.

Langeveld, J. H., Koot, H. M., \& Passchier, J. (1999). Do experienced stress and trait negative affectivity moderate the relationship between headache and quality of life in adolescents? Journal of Pediatric Psychology, 24, 1-11.

Larson, R. W. (2000). Toward a psychology of positive youth development. American Psychologist, 55, $170-183$. 
Larson, R. W., \& Richards, M. H. (1991). Daily companionship in late childhood and early adolescence: Changing developmental contexts. Child Development, 62, 284-300.

Lessing, E. E. (1972). Extension of personal future time perspective, age, and life satisfaction of children and adolescents. Developmental Psychology, 6, 457-468.

Leung, J. P., \& Leung, K. (1992). Life satisfaction, self-concept, and relationship with parents in adolescence. Journal of Youth and Adolescence, 21, 653-665.

Leung, C. Y. W., McBride-Chang, C., \& Lai, B. P. Y. (2004). Relations among maternal parenting style, academic competence, and life satisfaction in Chinese early adolescents. Journal of Early Adolescence, 24, 113-143.

Leung, C., Pe-Pua, R., \& Karnilowicz, W. (2006). Psychological adaptation and autonomy among adolescents in Australia: A comparison of Anglo-Celtic and three Asian groups. International Journal of Intercultural Relations, 30, 99-118.

Leung, J. P., \& Zhang, L. (2000). Modelling life satisfaction of Chinese adolescents in Hong Kong. International Journal of Behavioral Development, 24, 99-104.

Lewinsohn, P. M., Redner, J. E., \& Seeley, J. R. (1991). The relationship between life satisfaction and psychosocial variables: New perspectives. In F. Strack, M. Argyle \& N. Schwarz (Eds.), Subjective well-being: An interdisciplinary perspective (pp. 141-169). New York, NY: Pergamon Press.

Liebkind, K., \& Jasinskaja-Lahti, I. (2000). Acculturation and psychological well-being among immigrant adolescents in Finland: A comparative study of adolescents from different cultural backgrounds. Journal of Adolescent Research, 15, 446-469.

Liu, W., Tian, L., \& Gilman, R. (2005). A cross-cultural study on life satisfaction between Chinese and American middle-school students. Chinese Mental Health Journal, 19, 319-321.

Locke, E. A. (2002). Setting goals for life and happiness. In C. R. Snyder \& S. J. Lopez (Eds.), Handbook of positive psychology (pp. 299-312). New York: Oxford University Press.

Lombardi, D. N., Florentino, M. C., \& Lombardi, A. J. (1998). Perfectionism and abnormal behavior. The Journal of Individual Psychology, 54, 61-71.

Lopez, S. J., Snyder, C. R., Magyar-Moe, J. L., Edwards, L. M., Pedrotti, J. T., Janowski, K., et al. (2004). Strategies for accentuating hope. In P. A. Linley \& S. Joseph (Eds.), Positive psychology in practice (pp. 388-404). Hoboken, NJ: Wiley.

Lyubomirsky, S., King, L., \& Diener, E. (2005). The benefits of frequent positive affect: Does happiness lead to success? Psychological Bulletin, 131, 803-855.

MacDonald, J. M., Piquero, A. R., Valois, R. F., \& Zullig, K. J. (2005). The relationship between life satisfaction, risk-taking behaviors, and youth violence. Journal of Interpersonal Violence, 20, 14951518 .

Maddux, J. E. (2002). Self-efficacy: The power of believing you can. In C. R. Snyder \& S. J. Lopez (Eds.), Handbook of positive psychology (pp. 277-287). New York: Oxford University Press.

Man, P. (1991). The influence of peers and parents on youth life satisfaction in Hong Kong. Social Indicators Research, 24, 347-365.

Maslow, A., \& Richard, J. L. (1999). Toward a psychology of being. New York: Wiley.

Maton, K. I. (1990). Meaningful involvement in instrumental activity and well-being: Studies of older adolescents and at risk urban teen-agers. American Journal of Community Psychology, 18, 297-320.

McCrae, R. R., \& Costa, P. T. (1983). Social desirability scales: More substance than style. Journal of Consulting and Clinical Psychology, 51, 882-888.

McCullough, G., \& Huebner, E. S. (2003). Life satisfaction reports of adolescents with learning disabilities and normally achieving adolescents. Journal of Psychoeducational Assessment, 21, 311-324.

McCullough, G., Huebner, E. S., \& Laughlin, J. E. (2000). Life events, self-concept, and adolescents positive subjective well-being. Psychology in the Schools, 37, 281-290.

McFarlane, A. H., Bellissimo, A., \& Norman, G. R. (1995). Family structure, family functioning and adolescent well-being: The transcendent influence of parental style. Journal of Child Psychology and Psychiatry, 36, 847-864.

McKnight, C. G., Huebner, E. S., \& Suldo, S. M. (2002). Relationships among stressful life events, temperament, problem behavior, and global life satisfaction in adolescents. Psychology in the Schools, 39, 677-687.

Moore, D., \& Schultz, N. R. (1983). Loneliness at adolescence: Correlates, attributions, and coping. Journal of Youth and Adolescence, 12, 95-100.

Morojele, N. K., \& Brook, J. S. (2004). Sociodemographic, sociocultural, and individual predictors of reported feelings of meaninglessness among South African adolescents. Psychological Reports, 95, 1271-1278.

Myers, D. G., \& Diener, E. (1996). The pursuit of happiness. Scientific American, 274, 70-73. 
Neto, F. (1993). The Satisfaction With Life Scale: Psychometrics properties in an adolescent sample. Journal of Youth and Adolescence, 22, 125-134.

Neto, F. (1995). Predictors of satisfaction with life among second generation migrants. Social Indicators Research, 35, 93-116.

Neto, F. (2001). Satisfaction with life among adolescents from immigrant families in Portugal. Journal of Youth and Adolescence, 30, 53-67.

Newcomb, M. D., Bentler, P. M., \& Collins, C. (1986). Alcohol use and dissatisfaction with self and life: A longitudinal analysis of young adults. Journal of Drug Issues, 63, 479-494.

Nickerson, A. B., \& Nagle, R. (2004). The influence of parent and peer attachments on life satisfaction in middle childhood and early adolescence. Social Indicators Research, 66, 35-60.

Oishi, S., Diener, E., Lucas, R. E., \& Suh, E. M. (1999a). Cross-cultural variations in predictors of life satisfaction: Perspectives from needs and values. Personality and Social Psychology Bulletin, 25, 980990.

Oishi, S., Diener, E., Suh, E. M., \& Lucas, R. E. (1999b). Value as a moderator in subjective well-being. Journal of Personality, 67, 157-184.

Oliva, A., \& Arranz, E. (2005). Sibling relationships during adolescence. European Journal of Developmental Psychology, 2, 253-270.

Ortman, P. E. (1988). Adolescents' perceptions of and feelings about control and responsibility in their lives. Adolescence, 23, 913-924.

Park, N. (2005). Life satisfaction among Korean children and youth: A developmental perspective. School Psychology International, 26, 209-223.

Park, N., \& Huebner, E. S. (2005). A cross-cultural study of the levels and correlates of life satisfaction among adolescents. Journal of Cross-Cultural Psychology, 36, 444-456.

Park, N., Huebner, E. S., Laughlin, J. E., Valois, R. F., \& Gilman, R. (2004a). A cross-cultural comparison of the dimensions of child and adolescent life satisfaction reports. Social Indicators Research, 66, 61-79.

Park, N., \& Peterson, C. (2006a). Character strengths and happiness among young children: Content analysis of parental descriptions. Journal of Happiness Studies, 7, 323-341.

Park, N., \& Peterson, C. (2006b). Moral competence and character strengths among adolescents: The development and validation of the Values in Action Inventory of Strengths for Youth. Journal of Adolescence, 29, 891-909.

Park, N., Peterson, C., \& Seligman, M. E. (2004b). Strengths of character and well-being. Journal of Social and Clinical Psychology, 23, 603-619.

Patton, W., \& Noller, P. (1984). Unemployment and youth: A longitudinal study. Australian Journal of Psychology, 36, 339-413.

Peterson, C., \& Seligman, M. E. P. (2004). Character strengths and virtues: A classification and handbook. Washington, DC: American Psychological Association.

Phinney, J. S., \& Ong, A. D. (2002). Adolescent-parent disagreements and life satisfaction in families from Vietnamese- and European-American backgrounds. International Journal of Behavioral Development, 26, 556-561.

Piko, B. F., \& Keresztes, N. (2006). Physical activity, psychosocial health, and life goals among youth. Journal of Community Health, 31, 136-145.

Piko, B. F., Luszczynska, A., Gibbons, F. X., \& Tekozel, M. (2005). A culture-based study of personal and social influences of adolescent smoking. European Journal of Public Health, 15, 393-398.

Pinquart, M., Silbereisen, R. K., \& Juang, L. P. (2004). Moderating effects of adolescents' self-efficacy beliefs on psychological responses to social change. Journal of Adolescent Research, 19, 340-359.

Pretty, G., Rapley, M., \& Bramston, P. (2002). Neighbourhood and community experience, and the quality of life of rural adolescents with and without an intellectual disability. Journal of Intellectual and Developmental Disability, 27, 106-116.

Reynolds, C. R., \& Kamphaus, R. W. (1992). Manual for the Behavioral Assessment System for children. Circle Pines, MN: American Guidance Service, Inc.

Rigby, K. (2000). Effect of peer victimization in schools and perceived social support on adolescent wellbeing. Journal of Adolescence, 23, 57-68.

Rigby, B. T., \& Huebner, E. S. (2005). Do causal attributions mediate the relationship between personality characteristics and life satisfaction in adolescence? Psychology in the Schools, 42, 91-99.

Roberts, R. E., Alegria, M., Roberts, C. R., \& Chen, I. G. (2005). Concordance of reports of mental health functioning by adolescents and their caregivers: A comparison of European, African and Latino Americans. Journal of Nervous and Mental Disease, 193, 528-534.

Roberts, R. E., Roberts, C. R., \& Chen, I. G. (2002). Impact of insomnia on future functioning of adolescents. Journal of Psychosomatic Research, 53, 561-569. 
Sam, D. L. (1994). The psychological adjustment of young immigrants in Norway. Scandinavian Journal of Psychology, 35, 240-253.

Sam, D. L. (1998). Predicting life satisfaction among adolescents from immigrant families in Norway. Ethnicity \& Health, 3, 5-18.

Sam, D. L. (2000). Psychological adaptation of adolescents with immigrant backgrounds. Journal of Social Psychology, 140, 5-25.

Sastre, M. T. M., \& Ferriere, G. (2000). Family "decline" and the subjective well-being of adolescents. Social Indicators Research, 49, 69-82.

Schiff, M., Nebe, S., \& Gilman, R. (2006). Life satisfaction among Israeli youth in residential treatment care. British Journal of Social Work, 36, 1325-1343.

Schilmoeller, G. L., Baranowski, M. D., \& Higgins, B. S. (1991). Long-term support and personal adjustment of adolescent and older mothers. Adolescence, 26, 787-797.

Seligman, M. E. P. (2002a). Authentic happiness: Using the new possible psychology to realize your potential for lasting fulfillment. New York: Free Press.

Seligman, M. E. P. (2002b). Positive psychology, positive prevention, and positive therapy. In C. R. Snyder \& S. J. Lopez (Eds.), Handbook of positive psychology (pp. 3-9). New York: Oxford University Press.

Seligman, M. E. P., \& Csikszentmihalyi, M. (2000). Positive psychology: An introduction. American Psychologist, 55, 5-14.

Seligson, J., Huebner, E. S., \& Valois, R. F. (2003). Preliminary validation of the Brief Multidimensional Students' Life Satisfaction Scale (BMSLSS). Social Indicators Research, 61, 121-145.

Seligson, J., Huebner, E. S., \& Valois, R. F. (2005). An investigation of a brief life satisfaction scale with elementary school children. Social Indicators Research, 73, 355-374.

Shek, D. T. L. (1997a). Family environment and adolescent psychological well-being, school adjustment, and problem behavior: A pioneer study in a Chinese context. Journal of Genetic Psychology, 158, 113-128.

Shek, D. T. L. (1997b). The relation of family functioning to adolescent psychological well-being, school adjustment, and problem behavior. Journal of Genetic Psychology, 158, 467-479.

Shek, D. T. L. (1997c). The relation of parent-adolescent conflict to adolescent psychological well-being, school adjustment, and problem behavior. Social Behavior and Personality, 25, 277-290.

Shek, D. T. L. (1998a). A longitudinal study of Hong Kong adolescents' and parents' perceptions of family functioning and well-being. Journal of Genetic Psychology, 159, 389-403.

Shek, D. T. L. (1998b). A longitudinal study of the relations between parent-adolescent conflict and adolescent psychological well-being. Journal of Genetic Psychology, 159, 53-67.

Shek, D. T. L. (1998c). Adolescent positive mental health and psychological symptoms: A longitudinal study in a Chinese context. Psychologia: An International Journal of Psychology in the Orient, 41, 217-225.

Shek, D. T. L. (1999a). Individual and dyadic predictors of family functioning in a Chinese context. American Journal of Family Therapy, 27, 49-61.

Shek, D. T. L. (1999b). Parenting characteristics and adolescent psychological well-being: A longitudinal study in a Chinese context. Genetic, Social, and General Psychology Monographs, 125, $27-44$.

Shek, D. T. L. (1999c). Paternal and maternal influences on the psychological well-being of Chinese adolescents. Genetic, Social, and General Psychology Monographs, 125, 269-296.

Shek, D. T. L. (2002a). Family functioning and psychological well-being, school adjustment, and problem behavior in Chinese adolescent girls experiencing economic disadvantage. Family Therapy, 29, $33-48$.

Shek, D. T. L. (2002b). Family functioning and psychological well-being, school adjustment, and problem behavior in Chinese adolescents with and without economic disadvantage. Journal of Genetic Psychology, 163, 497-502.

Shek, D. T. L. (2002c). The relation of parental qualities to psychological well-being, school adjustment, and problem behavior in Chinese adolescents with economic disadvantage. American Journal of Family Therapy, 30, 215-230.

Shek, D. T. L. (2003a). A longitudinal study of parenting and adolescent adjustment in Chinese adolescents with economic disadvantage. International Journal of Adolescent Medicine and Health, 15, 39-49.

Shek, D. T. L. (2003b). Economic stress, psychological well-being and problem behavior in Chinese adolescents with economic disadvantage. Journal of Youth and Adolescence, 32, 259-266.

Shek, D. T. L. (2004). Chinese cultural beliefs about adversity: It's relationship to psychological well-being, school adjustment and problem behaviour in Hong Kong adolescents with and without economic disadvantage. Childhood, 11, 63-80.

Shek, D. T. L. (2005a). A longitudinal study of Chinese cultural beliefs about adversity, psychological wellbeing, delinquency and substance abuse in Chinese adolescents with economic disadvantage. Social Indicators Research, 71, 385-409. 
Shek, D. T. L. (2005b). A longitudinal study of perceived family functioning and adolescent adjustment in Chinese adolescents with economic disadvantage. Journal of Family Issues, 26, 518-543.

Shek, D. T. L. (2005c). Economic stress, emotional quality of life, and problem behavior in Chinese adolescents with and without economic disadvantage. Social Indicators Research, 71, 363-383.

Shek, D. T. L. (2005d). Paternal and maternal influences on the psychological well-being, substance abuse, and delinquency of Chinese adolescents experiencing economic disadvantage. Journal of Clinical Psychology, 63, 219-234.

Shek, D. T. L. (2005e). Perceived parental control processes, parent-child relational qualities, and psychological well-being in Chinese adolescents with and without economic disadvantage. Journal of Genetic Psychology, 166, 171-188.

Smith, D. C., Adelman, H. S., Nelson, P., Taylor, L., \& Phares, V. (1987). Students' perception of control at school and problem behavior and attitudes. Journal of School Psychology, 25, 167-176.

Snyder, C. R., Hoza, B., Pelham, W. E., Rapoff, M., Ware, L., Danovsky, M., et al. (1997). The development and validation of the Children's Hope Scale (CHS). Journal of Pediatric Psychology, 22, 399-421.

Snyder, C. R., Rand, K. L., \& Sigmon, D. R. (2002). Hope theory: A member of the positive psychology family. In C. R. Snyder \& S. J. Lopez (Eds.), Handbook of positive psychology (pp. 257-276). New York: Oxford University Press.

Steinberg, L. (1987). Impact of puberty on family relations: Effects of pubertal status and pubertal timing. Developmental Psychology, 23, 451-460.

Stevenson, W., Maton, K. I., \& Teti, D. M. (1999). Social support, relationship quality, and well-being among pregnant adolescents. Journal of Adolescence, 22, 109-121.

Stoiber, K. C., \& McIntyre, H. (2006). Adolescent pregnancy and parenting. In G. G. Bear \& K. M. Minke (Eds.), Children's needs III: Development, prevention, and intervention (pp. 705-719). Bethesda, MD: National Association of School Psychologists.

Suldo, S. M., \& Huebner, E. S. (2004a). Does life satisfaction moderate the effects of stressful events on psychopathological behaviour during adolescence? School Psychology Quarterly, 19, 93-105.

Suldo, S. M., \& Huebner, E. S. (2004b). The role of life satisfaction in the relationship between authoritative parenting dimensions and adolescent problem behavior. Social Indicators Research, 66, 165-195.

Suldo, S. M., \& Huebner, E. S. (2006). Is extremely high life satisfaction during adolescence advantageous? Social Indicators Research, 78, 179-203.

Tanaka, H., Mollborg, P., Terashima, S., \& Borres, M. P. (2005). Comparison between Japanese and Swedish schoolchildren in regards to physical symptoms and psychiatric complaints. Acta Paediatrica, 94, 1661-1666.

Terry, T., \& Huebner, E. S. (1995). The relationship between self-concept and life satisfaction in children. Social Indicators Research, 35, 39-52.

Thatcher, W. G., Reininger, B. M., \& Drane, J. W. (2002). Using path analysis to examine adolescent suicide attempts, life satisfaction and health risk behavior. Journal of School Health, 72, 71-77.

Ullman, C., \& Tatar, M. (2001). Psychological adjustment among Israeli adolescents immigrants: A report on life satisfaction, self-concept, and self-esteem. Journal of Youth and Adolescence, 30, 449-464.

Unger, D. G., \& Wandersman, L. P. (1988). The relation of family and partner support to the adjustment of adolescent mothers. Child Development, 59, 1056-1060.

Valle, M. F., Huebner, E. S., \& Suldo, S. M. (2004). Further evaluation of the Children's Hope Scale. Journal of Psychoeducational Assessment, 22, 320-337.

Valois, R. F., Paxton, R. J., Zullig, K. J., \& Huebner, E. S. (2006). Life satisfaction and violent behaviors among middle school students. Journal of Child and Family Studies, 15, 695-707.

Valois, R. F., Zullig, K. J., Huebner, E. S., \& Drane, J. W. (2001). Relationship between life satisfaction and violent behaviours among adolescents. American Journal of Health Behavior, 25, 353-366.

Valois, R. F., Zullig, K. J., Huebner, E. S., \& Drane, J. W. (2003). Dieting behaviors, weight perceptions, and life satisfaction among public high school adolescents. Eating Disorders: The Journal of Treatment \& Prevention, 11, 271-288.

Valois, R. F., Zullig, K. J., Huebner, E. S., \& Drane, J. W. (2004a). Life satisfaction and suicide among high school adolescents. Social Indicators Research, 66, 81-105.

Valois, R. F., Zullig, K. J., Huebner, E. S., \& Drane, J. W. (2004b). Physical activity behaviors and perceived life satisfaction among public high school adolescents. Journal of School Health, 74, 59-65.

Valois, R. F., Zullig, K. J., Huebner, E. S., Kammermann, S. K., \& Drane, J. W. (2002). Association between life satisfaction and sexual risk-taking behaviors among adolescents. Journal of Child \& Family Studies, 11, 427-440.

Van Selm, K., Sam, D. L., \& Van Oudenhoven, J. P. (1997). Life satisfaction and competence of Bosnian refugees in Norway. Scandinavian Journal of Psychology, 38, 143-149.

Veenhoven, R. (1988). The utility of happiness. Social Indicators Research, 20, 333-354. 
Veenhoven, R., \& Verkuyten, M. (1989). The well-being of only children. Adolescence, 24, 155-166.

Verkuyten, M. (1986). The impact of ethnic and sex differences on happiness among adolescents in the Netherlands. Journal of Social Psychology, 126, 259-260.

Verkuyten, M. (1989). Happiness among adolescents in the Netherlands: Ethnic and sex differences. Psychological Reports, 65, 577-578.

Vilhjalmsson, R. (1994). Effects of social support on self-assessed health in adolescence. Journal of Youth and Adolescence, 23, 437-452.

Vilhjalmsson, R., \& Thorlindsson, T. (1992). The integrative and physiological effects of sport participation: A study of adolescents. Sociological Quarterly, 33, 637-647.

Virta, E., Sam, D. L., \& Westin, C. (2004). Adolescents with Turkish background in Norway and Sweden: A comparative study of their psychological adaptation. Scandinavian Journal of Psychology, 45, 15-25.

Wenk, D. A., Hardesty, C. L., Morgan, C. S., \& Blair, S. L. (1994). The influence of parental involvement on the well-being of sons and daughters. Journal of Marriage \& the Family, 56, 229-234.

West, M. O., \& Prinz, R. J. (1987). Parental alcoholism and childhood psychopathology. Psychological Bulletin, 102, 204-218.

Wilson, S. M., Henry, C. S., \& Peterson, G. W. (1997). Life satisfaction among low-income rural youth from Appalachia. Journal of Adolescence, 20, 443-459.

Wilson, S. M., \& Peterson, G. W. (1988). Life satisfaction among young adults from rural families. Family Relations, 37, 84-91.

Wood, V., Whylie, M., \& Sheafor, B. (1969). An analysis of a short self-report measure of life satisfaction: Correlation with rater judgments. Journal of Gerontology, 24, 465-469.

Young, M. H., Miller, B. C., Norton, M. C., \& Hill, E. J. (1995). The effect of parental supportive behaviors on life satisfaction of adolescent offspring. Journal of Marriage and Family, 57, 813-822.

Zimmerman, M. A., Salem, D. A., \& Maton, K. I. (1995). Family structure and psychosocial correlates among urban African-American adolescent males. Child Development, 66, 1598-1613.

Zullig, K. J., Valois, R. F., Huebner, E. S., \& Drane, J. W. (2005a). Adolescent health-related quality of life and perceived satisfaction with life. Quality of Life Research: An International Journal of Life Aspects of Treatment, Care and Rehabilitation, 14, 1573-1584.

Zullig, K. J., Valois, R. F., Huebner, E. S., \& Drane, J. W. (2005b). Associations among family structure, demographics, and adolescent perceived life satisfaction. Journal of Child \& Family Studies, 14, 195206.

Zullig, K. J., Valois, R. F., Huebner, E. S., Oeltmann, J. E., \& Drane, J. W. (2001). Relationship between perceived life satisfaction and adolescents' substance abuse. Journal of Adolescent Health, 29, 279288 . 